\title{
Cash Holdings and Labor Heterogeneity: The Role of Skilled Labor
}

\author{
Mohamed Ghaly $^{\mathrm{a}}$, Viet Anh Dang ${ }^{\mathrm{b}}$, and Konstantinos Stathopoulos ${ }^{\mathrm{c}}$
}

February 22, 2017

Review of Financial Studies, forthcoming

\begin{abstract}
Firms differ in their dependence on skilled labor, and face labor adjustment costs that increase with their workers' skill level. We show that firms with a higher share of skilled workers, and thus less flexibility to adjust their labor demand in response to cash flow shocks, hold more precautionary cash. The effect of labor skills on cash holdings is more pronounced for financially constrained firms and varies with exogenous differences in firing and hiring costs. We address endogeneity concerns by using subsamples of firms with reasonably similar characteristics, propensity score matching, and a quasi-experimental shock to labor markets.
\end{abstract}

JEL Classifications: G32, G34, M54.

Keywords: Cash Holdings, Skilled Labor, Labor Adjustment Costs, Labor Heterogeneity.

\footnotetext{
${ }^{*}$ We are grateful to an anonymous referee and the Editor (David J. Denis) for invaluable comments and suggestions that have greatly improved the paper. We would also like to thank Ashwini Agrawal, Heitor Almeida, Michael Brennan, Murillo Campello, Sudipto Dasgupta, Marie Dutordoir, Susanne Espenlaub, Michael Faulkender, Chris Florackis, Ning Gao, Ian Garrett, Yaniv Grinstein, Hans Hvide, Ambrus Kecskés, Arif Khurshed, Sandy Klasa, Mauricio Larrain, Kai Li, Gyongyi Loranth, Maria Marchica, Joan Farre-Mensa, Roberto Mura, Oksana Pryshchepa, Martin Schmalz, Merih Sevilir, Norman Strong, Karin Thorburn, and seminar participants at Cardiff Business School, International Hellenic University, Strathclyde Business School, University of Bristol, Warwick Business School, and University of Birmingham for their helpful comments and suggestions on previous versions of the paper. The usual disclaimer applies.

${ }^{a}$ Lancaster University Management School, Lancaster University, m.ghaly@lancaster.ac.uk, Tel: +44 (0)1524 594526 (Corresponding author).

${ }^{\mathrm{b}}$ Alliance Manchester Business School, University of Manchester, vietanh.dang@manchester.ac.uk.

cAlliance Manchester Business School, University of Manchester, k.stathopoulos@manchester.ac.uk.
} 


\section{Introduction}

Labor is a heterogeneous factor of production and differences in workers' skill sets are a major source of this heterogeneity. While some firms rely heavily on highly skilled employees for their operations, others utilize predominantly low-skilled workers. In this paper, we investigate how a firm's reliance on skilled labor affects its cash management policy.

The theoretical link between workers' skill level and cash holdings is based on an important friction in the labor market, namely, the costs of labor adjustment. When a firm adjusts its labor demand, it incurs the costs of firing, search, selection, hiring, and training, as well as costs associated with productivity losses. These costs are economically significant, amounting to a one-year payroll cost for the average worker, and increase with the skill level of the labor force (e.g., Oi 1962; Shapiro 1986). In the presence of labor adjustment costs (LACs), a firm cannot adjust its labor demand costlessly and has an incentive to minimize its labor turnover (Dixit 1997). Failure to follow this optimal labor retention policy is particularly costly for firms relying on skilled employees, who are more likely to receive higher severance payments or file lawsuits if fired. Furthermore, searching, hiring, and training employees are more costly, for jobs that require advanced technical skills, which are usually in shorter supply (Manning 2003; Dolfin 2006; Blatter, Muehlemann, and Schenker 2012). This difficulty means that replacing skilled workers typically takes longer (Oi 1962), causing greater disruption to productivity. In addition, employee layoffs, as a cost-cutting response to demand slumps, have a negative effect on a firm's stock price performance (Farber and Hallock 2009); the higher the skill level of the human capital laid off, the more pronounced the effect (Milanez 2012).

The above arguments suggest that firms should avoid making costly labor adjustments by optimally maintaining employment at a stable level. This labor retention policy, however, exposes them to the risk of not being able to mitigate the impact of future cash flow shocks. We expect firms to have an incentive to hold precautionary cash to reduce this risk because cash reserves act as a buffer that safeguards against future cash flow uncertainty (Almeida, Campello, and Weisbach 2004; Han and Qiu 2007), thus enabling firms to maintain their optimal employment policy. Moreover, we argue that this precautionary motive for holding cash is stronger for firms that depend heavily on 
skilled workers. The greater a firm's reliance on skilled labor, the higher the costs of labor adjustment it faces and the stronger the incentive for the firm to retain skilled workers and hold precautionary cash. This argument is broadly consistent with Baghai et al. (2015) and Brown and Matsa (2016), who report that firms should adopt conservative financial policies to reduce the probability of distress as well as the labor-related costs of retaining and recruiting high-quality employees in distressed situations. In sum, we hypothesize that a firm's reliance on skilled labor has a positive effect on its cash holdings.

Crucial to our empirical analysis is the measurement of a firm's reliance on skilled labor. As in Ochoa (2013) and Belo et al. (forthcoming), we construct an industry-specific labor skill index (LSI) based on Occupational Employment Statistics (OES) data from the Bureau of Labor Statistics (BLS) and the O*NET program classification of occupations according to skill level. The O*NET skill level classifications are based on how much education, related work experience, and training an employee needs to perform a given job at a competent level. LSI measures the weighted average skill level of the occupations within an industry and proxies for the LACs the average firm in that industry faces.

Using LSI as a measure of labor skills, we find strong evidence that firms operating in industries with a higher share of skilled workers hold larger cash balances, which is consistent with our hypothesis. The impact of LSI on cash holdings is economically significant: A one standard deviation increase in the index is associated with an increase in the cash-to-assets ratio of 4.2 percentage points, which translates to a $21.2 \%$ increase in the cash ratio relative to the sample mean. This positive association is robust to a variety of model specifications, including fixed effects regressions in which we control for firm and industry heterogeneity, as well as alternative definitions of both cash and labor skills.

A major concern with a causal interpretation of the relation between LSI and cash holdings is the potential endogeneity of labor skills. A firm's share of skilled labor may be endogenously chosen and related to unobservable factors that also affect its cash holdings, leading to a spurious correlation. We note that, by controlling for firm and industry fixed effects in our baseline regressions, we address one source of endogeneity that may lead to potential firm and industry heterogeneity bias. Reverse 
causality poses yet another concern. A firm's cash holdings may affect its ability to recruit skilled workers, implying causality from cash to $L S I$. We address these endogeneity concerns through three different strategies that involve using subsamples of industries and firms with reasonably similar characteristics, propensity score matching (PSM), and a quasi-natural experiment associated with exogenous variation in the costs of labor adjustment, the mechanism driving the relation between LSI and cash holdings.

First, we run our analyses using subsamples of industries and firms with reasonably similar observable and unobservable characteristics. In addition to performing the fixed effects regressions mentioned above, these tests further reduce firm and industry heterogeneity bias. We focus on industries with above-median LSI (i.e., high-skill industries) as well as manufacturing industries and then double-sort firms along these dimensions and examine a subsample of manufacturing and highskill industries. The subsample results are similar to our baseline findings in that labor skills have a positive and significant impact on cash holdings. Second, we perform a series of PSM analyses to reduce heterogeneity along many dimensions as opposed to the single- or double-sorting used in the first test. Specifically, we match high-skill firms with low-skill firms on year, industry, and all the control variables using the whole sample or subsamples of similar firms. Our analyses of the treatment (high-skill) and matched (low-skill) firms again show that firms with greater reliance on skilled labor hold more cash.

Our final strategy exploits an exogenous shock to the labor supply as a result of labor migration from New Orleans to Houston following Hurricane Katrina in 2005. Between 100,000 and 150,000 evacuees made the move, representing a $3 \%-4 \%$ increase in the Houston population (McIntosh 2008). Given that those evacuees consisted of both highly and low-skilled workers (Gabe et al. 2005; McIntosh 2008; De Silva et al. 2010), the Katrina-induced increase in the labor supply should increase the thickness (i.e., the number of effective participants) of Houston's local labor market (Moretti 2011) and therefore result in lower LACs on average for firms headquartered in Houston compared to matched control firms. Moreover, we argue that the negative impact of the labor migration following Hurricane Katrina on LACs should be more pronounced for high-skill Houstonbased firms, for at least two reasons. First, because the LACs of skilled workers are considerably 
higher in magnitude than those of unskilled workers, modest and comparable percentage reductions in the LACs of both types of workers should lead to a much greater decrease in absolute terms in the LACs faced by high-skill firms. Second, the increased thickness of Houston's local labor market is likely to reduce the probability of not filling a vacancy more for jobs requiring advanced skills than for unskilled jobs and to improve the employee-firm match quality more for highly skilled specialized employees than for low-skilled manual laborers (Moretti 2011; Bleakley and Lin 2012). Thus, the Katrina-induced migration to Houston should exert a stronger impact on the LACs of highly skilled workers than those of low-skilled workers. Based on these arguments, we expect Houston-based firms, in particular those with a greater share of skilled workers, to have had a lower precautionary savings motive for holding cash than the control firms. Using treatment firms headquartered in the Houston metropolitan area and matched firms headquartered in neighboring metropolitan areas, we run a difference-in-differences regression as well as a triple-difference specification with continuous treatment, the latter regression enabling us to capture the impact of exogenous variation in LACs on cash holdings conditional on different levels of LSI. Consistent with our predictions, the coefficients on the double- and triple-difference terms are negative and significant. Overall, while it is difficult to completely rule out endogeneity concerns, taken together, our three tests all provide consistent evidence of a causal effect of LSI on cash holdings.

We next examine variation in the relation between $L S I$ and cash holdings taking into account (a) state-level differences in the costs of downward and upward labor adjustments (firing versus hiring costs) and (b) firm-level differences in the precautionary motive for holding cash. First, we follow Serfling (2016) and exploit exogenous variation in the costs of firing following the state-level recognition of wrongful discharge laws (WDLs). Firms in states with stronger employment protection laws face higher firing costs, giving them a stronger precautionary motive to build up cash reserves. We further expect the effect of WDLs on firing costs to be more pronounced for high-skill firms because WDLs pertain generally to full-time and nonunionized workers, who are typically more skilled. Additionally, skilled workers are more likely to litigate, thereby resulting in higher litigation risk and higher lawsuit costs for high-skill firms. We then investigate the impact of exogenous variation in the costs of hiring for firms headquartered in states that provide hiring credits (i.e., 
subsidies for companies that hire workers). We conjecture that the existence of high-quality hiringcredit programs leads to lower costs of hiring, thus weakening the precautionary motive for holding cash. In addition, the impact of these programs on hiring costs is more pronounced for high-skill firms because a large number of high-quality hiring-credit programs aims at creating high-quality, high-pay jobs and, hence, are likely to target firms that require skilled labor, given the positive correlation between wages and labor skills. Consistent with those predictions, we find that the relation between LSI and cash holdings is more (less) pronounced the higher (lower) the firing (hiring) costs resulting from the recognition of WDLs (the availability of high-quality hiring-credit programs). Moreover, to the extent that WDLs and hiring credits proxy, respectively, for (state-level) variations in firing and hiring costs, our results also suggest that the impact of $L S I$, as a broader measure of LACs, on cash holdings is above and beyond the impacts of those individual proxies for LACs.

Second, we examine subsamples of firms that are financially unconstrained as well as those that are financially constrained, for which the precautionary savings motive is most relevant (Almeida, Campello, and Weisbach 2004, 2011). We find that the effect of skilled labor on cash holdings is indeed stronger for firms that are constrained, which gives further support to the precautionary motive explanation.

We next report results from several tests that aim to alleviate concerns about mechanisms other than LACs driving our results. In particular, we address the concern that our results are primarily driven by a different channel relating to intangible capital. Skilled workers hold firmspecific organizational capital and proprietary information that are typically embodied in key personnel (Brown and Petersen 2011; Eisfeldt and Papanikolaou 2013). Thus, firms with skilled labor may seek to protect valuable intangible assets, rather than labor skills, by holding precautionary cash. While the two channels (i.e., LACs and intangible capital) are not mutually exclusive and are thus difficult to disentangle, our tests show that the relation between labor skills and cash holdings remains positive and significant when we control for intangible capital using proxies established in recent studies (Peters and Taylor 2017) or concentrate on firms that have limited intangible capital. Taken together, these tests suggest that our findings are consistent with the LACs mechanism and not simply driven by an intangible capital channel. 
The main contribution of our study is that we provide novel evidence of the effect of skilled labor on cash holdings. While recent theoretical research has shown how cash holdings are related to labor-related considerations (Karabarbounis and Neiman 2012; Boeri, Garibaldi, and Moen 2014; Bacchetta, Benhima, and Poilly 2015), only a few empirical studies have examined the effect of labor market frictions on corporate cash policies. Klasa, Maxwell, and Ortiz-Molina (2009) focus on the bargaining role of cash when dealing with union pressures and show that a firm facing stronger unions will strategically hold less cash to improve its bargaining position. Schmalz (2015) studies how cash can help firms regain financial flexibility following an exogenous increase in labor rigidity after unionization and argues that the interaction between unionization and cash holdings can be driven by an incentive to manage human capital risk. We note that these two studies focus on the impact of unionization on cash, and neither explicitly considers heterogeneity in the labor skill level. Labor rigidity from unionization is mainly related to low-skilled workers, who primarily have the incentive to unionize. In contrast, our focus is on highly skilled labor and the impact of heterogeneity in labor skills on cash holdings.

Our study is related to a growing theoretical and empirical body of literature examining the interaction between frictions in the labor market and corporate capital structure. This literature seeks to explain firms' leverage decisions through a number of labor-related considerations such as the human costs of bankruptcy (Berk, Stanton, and Zechner 2010), strategic bargaining with labor unions (Matsa 2010), employee treatment (Bae, Kang, and Wang 2011), unemployment risk (Agrawal and Matsa 2013), and labor market size (Kim 2015). In particular, recent research by Kuzmina (2013), Simintzi, Vig, and Volpin (2015), and Serfling (2016) exploits exogenous changes in firing costs resulting from the use of temporary workers or the passage of employment protection laws and provides consistent evidence that financial leverage is negatively related to labor rigidity. Our findings contribute to existing evidence by showing that high-labor-skill firms with high LACs follow conservative financial policies by holding more cash. Moreover, by using labor skills as a proxy for the costs of labor adjustment encompassing both firing and hiring costs, our study adds to prior research that has mainly focused on the impact of firing costs on financial leverage. 
Our results also contribute to the established literature investigating the determinants of corporate cash holdings. Existing studies identify a number of factors affecting cash management policies (e.g., Opler et al. 1999; Bates, Kahle, and Stulz 2009; Azar, Kagy, and Schmalz 2016); see Almeida et al. (2014) for a recent survey of the literature. Our paper proposes workers' skill level as a new and important determinant of cash holdings.

Finally, our paper is closely related to the two recent studies mentioned earlier, by Ochoa (2013) and Belo et al. (forthcoming), which also consider the implications of labor heterogeneity. However, their focus differs from ours as they examine the impact of labor skills on asset prices. They show that firms with a high share of skilled labor have higher stock returns because they carry more risk and are more exposed to aggregate shocks in the economy. To the best of our knowledge, our study is the first to investigate the interaction between workers' skill level and firms' financial policies with a focus on cash holdings.

\section{Hypothesis Development}

Why does skilled labor matter for corporate cash policy? We argue that cash holdings are important to firms facing labor market frictions due to the presence of costly labor adjustment. Our argument combines two strands of literature, on LACs and on the precautionary savings motive. In the labor economics literature, Oi (1962) introduces the premise that labor is a quasi-fixed factor such that firms incur costs when they adjust their labor demand. Examples of these costs include the costs of firing (e.g., severance pay, lawsuits), search (e.g., recruitment agency fees, advertising), selection and hiring (e.g., application screening, interviews), training, and costs associated with productivity losses (e.g., peer and supervisor disruption). Existing evidence shows that the LACs are economically significant and hence act as an important friction in the labor market (e.g., Pfann and Palm 1993; Hamermesh 1989, 1995; Manning 2006; Dube, Freeman, and Reich 2010).

Prior studies further show that the costs of labor adjustment are not fixed but increase with the labor skill level. This is because skilled workers are more likely to receive larger amounts of severance pay or to file lawsuits if laid off, hence increasing firing costs for high-skill firms (Dertouzos, Holland, and Ebener 1988; Autor, Donohue, and Schwab 2006). Similarly, the costs of 
hiring can be higher for high-skill firms because the search, selection, and recruitment processes are likely to be harder and more demanding for jobs that require advanced technical talents, which are usually in shorter supply (Manning 2003; Dolfin 2006). Oi (1962), for example, estimates the average lag between workers leaving a firm and being replaced to be longer for jobs with higher skill requirements, implying higher costs due to productivity disruption. In addition, a highly skilled job typically requires the incoming worker to undergo costly advanced training in the complex tasks he or she will perform. Indeed, the argument that LACs increase with workers' skill level is well supported by existing evidence (Dube, Freeman, and Reich 2010; Blatter, Muehlemann, and Schenker 2012; Blatter et al. 2016).

The presence of economically significant LACs, especially those of skilled labor, provides firms with an incentive to optimally retain workers and minimize labor turnover (Oi 1962; Dixit 1997). In light of recent research on the precautionary savings motive (e.g., Almeida, Campello, and Weisbach 2004), we argue that firms that seek to follow this optimal labor retention policy have an incentive to hold precautionary cash. In the presence of financing frictions, cash reserves allow a firm to hedge against future cash flow volatility (Han and Qiu 2007) while maintaining its optimal labor employment policy. $^{2}$ We expect the precautionary savings motive to be stronger for firms with a higher share of skilled workers. The reason is that firms that rely more on skilled labor face higher LACs, which in turn slow their labor-demand reaction to cash flow shocks and generally reduce their ability to smooth unexpected future cash flows. In sum, we hypothesize that the degree to which a firm relies on skilled labor has a positive effect on its cash holdings.

\footnotetext{
${ }^{1}$ For example, using the 2003 and 2008 waves of the California Establishment Survey, Dube, Freeman, and Reich (2010) estimate the hiring costs per person in 2003 dollars to be $\$ 2,000$ for blue collar and manual labor workers and $\$ 7,000$ for professional and managerial employees.

${ }^{2}$ Although a firm can use alternatives to cash holdings, such as lines of credit, hedging, and unused debt capacity, cash remains the preferred choice (Almeida et al. 2014). Acharya, Almeida, and Campello (2013) show that firms with large liquidity risks tend to favor cash if their liquidity risk is aggregate in nature.
} 


\section{Data and Summary Statistics}

\subsection{Measuring the Reliance on Skilled Labor}

We construct an index to measure the extent of a firm's reliance on skilled labor using the OES data from the BLS and the U.S. Department of Labor's O*NET program classification of occupations based on skill level. ${ }^{3}$ Formally, we define this index as

$$
L S I_{i}=\sum_{j=1}^{O}\left(\frac{E_{j i}}{E_{i}} * Z_{j}\right),
$$

where $E_{j i}$ is the number of employees in industry $i$ working in occupation $j, E_{i}$ is the total number of employees in industry $i, O$ is the total number of occupations in industry $i$, and $Z_{j}$ is the $\mathrm{O}^{*} \mathrm{NET}$ program classification. The latter program classifies occupations into five job zones, ranging from job zone 1, which includes occupations that require little or no skill, to job zone 5, which consists of occupations that require extensive skill sets. These skill-level classifications are based on how much education, related work experience, and training an employee needs to perform a job at a competent level. ${ }^{4}$ By construction, LSI is an industry-level index that measures the weighted-average skill level of the occupations within an industry, ranging from 1 to 5 . A low score implies that the majority of workers in the industry requires little or no skill to perform their jobs, while a high score indicates that a large share of the industry's workers needs extensive skill levels to perform their jobs adequately. We classify industries using three-digit Standard Industrial Classification (SIC) codes for pre-2002 data and four-digit North American Industry Classification System (NAICS) codes for 2002 data and beyond (Donangelo 2014; Belo et al., forthcoming). Our approach of using the distribution of skilled occupations within an industry to proxy for firms' reliance on skilled labor and their LACs is similar to approaches adopted in recent studies (Ochoa 2013; Donangelo 2014; Belo et al., forthcoming).

Table 1 presents the average values of $L S I$ for several industries. The results reveal important (cross-sectional) variation in LSI. For the purpose of illustration, we focus on industries with the

\footnotetext{
${ }^{3}$ The OES dataset is based on surveys that track employment across occupations and industries and covers about 200,000 non-farm establishments in the U.S. every six months, not including self-employed workers.

${ }^{4}$ The detailed job-zone classifications are available at http://www.onetonline.org/help/online/zones.
} 
highest and lowest degrees of reliance on skilled workers (i.e., high- and low-skill industries). At the high end, as expected, high-skill industries include legal services, engineering and architectural services, accounting and tax preparation services, and scientific R\&D services. At the low end, gasoline stations, services to buildings, grocery stores, and eating and drinking establishments are examples of low-skill industries.

\subsection{Sample Selection and Variables}

We first use the OES dataset to obtain industry-level occupational data for $1999-2012 .{ }^{5} \mathrm{Next}$, we merge these data with job-zone (occupational) skill-level classifications from the O*NET program. Starting with the population of Compustat firms over the same sample period, we use a firm's industry membership, defined by the three-digit SIC code pre-2002 or the four-digit NAICS code from 2002 onward, to match the firm with a corresponding LSI score. We exclude firms with missing data for the main variables in our regressions. Consistent with the extant literature, we also exclude financial firms and utilities (i.e., firms with SIC codes between 6000 and 6999 or 4900 and 4999).

The dependent variable in our regressions is cash holdings, which we measure using the ratio of cash and short-term investments to total assets. However, our results are robust to alternative measures of cash holdings, as reported in Section 5.2. In terms of the control variables, we follow Bates, Kahle, and Stulz (2009) and include the following determinants of cash holdings: cash flow, net working capital, capital expenditures, leverage, acquisitions, Tobin's Q (market to book), size, industry cash flow volatility, and R\&D expenditures; see Table 2 for detailed variable definitions. We winsorize these variables at the 1st and 99th percentiles of their distributions to mitigate the effect of

\footnotetext{
${ }^{5}$ Although the OES data are available from 1988, we start our sample in 1999 for two reasons. First, prior to 1997, the OES data were collected over three-year survey cycles, meaning that the data for each industry were updated once every three years. The frequency of the data collection only increased to an annual cycle starting in 1997. Second, the O*NET program uses the Standard Occupational Classification (SOC) taxonomy to define occupations. The OES dataset only began to use the same SOC taxonomy in 1999.
} 
outliers. The final sample has 68,057 firm-year observations representing 10,760 unique firms covering 1999-2012.

\subsection{Summary Statistics}

Table 2 reports summary statistics for cash holdings, LSI, and the control variables in the baseline specification. The mean and median cash holdings in our sample are $19.8 \%$ and $10.5 \%$, respectively. These figures are in line with Bates, Kahle, and Stulz (2009), who report mean (median) cash holdings ranging from $19.4 \%$ to $24.0 \%(7.7 \%$ to $14.8 \%)$ for $1999-2006$. LSI has a mean and standard deviation of 2.471 and 0.501 , respectively, which are very close to the figures reported in recent studies. For example, Ochoa (2013) reports an average LSI of 2.668, with a standard deviation of 0.448 .

Table 3 shows the results of a univariate analysis conducted to compare the characteristics of firms with above- and below-median LSI scores (i.e., high- and low-labor-skill firms). Column 1 reports the average characteristics of all firms in the sample. Columns 2 and 3 present the mean characteristics of high- and low-skill firms, respectively. Column 4 reports the significance levels for the $t$-tests of differences in the mean characteristics. ${ }^{6}$ Column 5 reports the significance levels of differences when we perform the $t$-tests allowing the standard errors to be clustered at the industry level. Our comparison reveals that firms that rely more on skilled labor hold more cash. Specifically, the average cash holdings are $26.1 \%$ for high-skill firms compared to $13.6 \%$ for low-skill firms. The difference of 12.5 percentage points is statistically significant at the $1 \%$ level, whether the standard errors are clustered or not, and is economically significant as it amounts to $63 \%$ of the cash balances of the average firm in our sample (19.8\%). We also find that firms that rely more on skilled labor tend to be smaller, pay out less in dividends, have better growth opportunities, use less financial leverage, invest more in R\&D, and operate in industries with more volatile cash flows. However, the differences in these characteristics are not always statistically significant between the high and low LSI groups once we allow for clustering of the standard errors.

\footnotetext{
${ }^{6}$ Tests based on median firm characteristics provide similar results, but are omitted to conserve space.
} 


\section{Empirical Results}

\subsection{Cash Holdings and Skilled Labor: Main Results}

Table 4 presents the regression results on the relation between the degree to which firms rely on skilled labor and their cash holdings. Since our key test variable, LSI, is measured at the industry level, we report $p$-values based on heteroskedasticity-robust standard errors, clustered at the industry level. The only exception is Model 4, where we perform a cross-sectional regression using industry time-series averages and thus report $p$-values based on non-clustered heteroskedasticity-robust standard errors. All regressions include year fixed effects (except for the cross-sectional specifications in Models 3 and 4).

In Model 1, we perform a pooled ordinary least squares (OLS) estimation and regress cash holdings on the control variables mentioned above. For brevity, we do not discuss these results here, but note that they are broadly consistent with previous evidence in the literature (e.g., Bates, Kahle, and Stulz 2009) and in line with theoretical predictions regarding their effects on cash holdings. In Model 2, we include $L S I$ as an additional explanatory variable and find that the coefficient on LSI is positive and highly significant. It is also economically significant at 0.084 as a one standard deviation increase in the index is associated with an increase in the cash-to-total assets ratio of 4.2 percentage points, which translates to a $21.2 \%$ increase in the cash ratio relative to the sample mean. The coefficients on the other explanatory variables are quite similar to those in Model 1, suggesting that the effect of $L S I$ on cash holdings is not driven by its correlation with these firm characteristics.

We next investigate how the cross-sectional variation in cash holdings is determined by LSI. In Model 3, we perform a cross-sectional regression using the firm-specific time-series means of the variables. As in Model 2, the coefficient on LSI (0.095) is significantly positive, but it is $13 \%$ greater in magnitude than in the former model. This finding suggests a strong cross-sectional relation between labor skills and cash holdings.

In Model 4, we employ a cross-sectional specification that resembles Model 3 but uses aggregate data at the industry level. That is, instead of using firm-specific, time-series averages, we use industry time-series averages, where industries are defined by three-digit industry SIC codes. The 
coefficient on LSI (0.028) remains positive and significant, indicating that industry-level cash holdings are determined by differences in the reliance on skilled labor across industries.

In Models 5 and 6, we perform two fixed effects regressions to control for firm and industry (three-digit SIC codes) fixed effects, respectively. Despite the persistence of the labor skill level over time, ${ }^{7}$ we include these fixed effects to address a concern that not controlling for unobserved timeinvariant firm- or industry-level factors (i.e., heterogeneity) may lead to a spurious correlation between LSI and cash holdings. The results show that the coefficient on LSI remains positive and significant at the $1 \%$ level, although its magnitude is smaller than in the baseline regression (Model 2). Comparing these results with those for Models 2-4, we conclude that the variation in cash holdings is mainly driven by cross-sectional differences in LSI.

Overall, our findings are qualitatively similar across a variety of model specifications: LSI has a robust and positive impact on cash holdings. This evidence is consistent with our hypothesis that firms relying heavily on skilled workers hold higher cash balances so as to follow an optimal labor retention policy, as implied by the higher LACs they face.

\subsection{Addressing Endogeneity Concerns}

A concern with our regression results so far is the potential endogeneity of LSI. A firm's dependence on skilled labor may be related to unobservable factors affecting its cash policy, leading to a spurious relation between LSI and cash holdings. Our fixed effects regressions in Models 5 and 6 of Table 4 control for firm and industry heterogeneity and thus alleviate to an extent the omittedvariable bias. Reverse causality is another possibility. A liquid balance sheet may improve a firm's ability to recruit skilled workers from the labor market, meaning that cash holdings may affect the firm's dependence on skilled labor. In the following subsections, we attempt to establish the causal link between labor skills and cash holdings through three different strategies.

\footnotetext{
${ }^{7}$ Our (unreported) analysis shows that $L S I$ is rather persistent, displaying more variation across industries than in the time series.
} 


\subsubsection{Subsamples of Industries with Similar Characteristics}

To address the possibility that the relation between LSI and cash holdings may be confounded by unobserved firm and industry heterogeneity, we examine subsamples of relatively similar industries and firms. First, we remove from our sample low-skill firms, which are likely to differ significantly from their high-skill counterparts in terms of unobserved characteristics, and focus on a subsample of the latter firms, that is, firms operating in industries with above-median LSI. Next, we look at a subsample of firms in the manufacturing sector (with SIC codes between 2000 and 3999) as well as a more focused subsample of manufacturing and high-skill firms. By examining relatively similar firms in a single sector, our tests reduce industry heterogeneity and help alleviate the omittedvariable bias. The results reported in Table 5 show that the coefficient on LSI continues to be significant for these subsamples of relatively similar firms, suggesting that the positive relation between $L S I$ and cash is unlikely to be affected by heterogeneity bias.

\subsubsection{Propensity Score Matching}

To control for observable differences in firm and industry attributes, we next perform a PSM analysis. We match firms with above-median LSI with those with below-median LSI on year, industry, and all the control variables from our baseline regression. ${ }^{8}$ By matching on industry (using two-digit SIC codes), ${ }^{9}$ we can also remove unobserved industry heterogeneity that may be correlated with our measure of labor skills. The results in Table 6 suggest that, as expected, firms with high labor skills hold more cash than propensity-score-matched firms with low labor skills $(0.261$ versus 0.177$)$, the difference $(0.084)$ being significant at the $1 \%$ level. This finding holds whether the standard errors are bootstrapped (Column 3) or clustered at the industry level (Column 4).

\footnotetext{
${ }^{8}$ In all specifications, we apply the nearest neighbor matching algorithm, with replacement and common support. Standard errors are either bootstrapped to take into account the fact that propensity scores are estimated rather than known (Abadie and Imbens 2006) or clustered at the industry level. The balancing property is satisfied in all models.

${ }^{9}$ We use two-digit SIC codes in our matching to retain some variation in LSI, which is constructed for each industry according to its three-digit SIC code.
} 
As in Table 5, we further look at subsamples of industries and firms that have reasonably similar characteristics. That is, we match manufacturing firms with above-median LSI with those in the same sector with below-median LSI. We also perform the matching for a subsample of firms in highlabor-skill industries as well as for separate subsamples of positive- and zero-R\&D firms. Using the subsamples of positive-R\&D firms and high-skill industries enables us to focus on firms that rely relatively more heavily on skilled workers, for which we expect the impact of LSI on cash holdings to be most pronounced.

Consistent with our hypothesis, all sub-sample results exhibit significant differences in the cash balances of high- and low-labor-skill firms operating in the same (manufacturing) or similar (high-labor-skill) sectors and having similar characteristics (positive or zero R\&D expenses). Specifically, the differences are strongly significant when the standard errors are bootstrapped; they remain significant at the $5 \%(10 \%)$ level for high-skill industries and positive-R\&D firms (manufacturing industries and zero-R\&D firms) when the standard errors are clustered at the industry level. In terms of magnitude, these differences vary between 0.019 and 0.106 , being smallest for the subsample of zero-R\&D firms and largest for the subsample of manufacturing firms. We note, however, that in relative terms, the difference (0.019) in the cash ratio of high- and low-skill zeroR\&D firms represents $14.2 \%(16.5 \%)$ of the mean cash ratio of zero-R\&D firms with above-(below)median LSI, which is economically significant.

\subsubsection{Exogenous Shock to Labor Markets: Hurricane Katrina}

Our final strategy exploits an exogenous shock to the labor supply that occurred as a result of labor migration from New Orleans to Houston following Hurricane Katrina. Based on Current Population Survey (CPS) data for November 2005 through August 2006, McIntosh (2008) reports a figure of between 100,000 and 150,000 such evacuees, representing a 3\%-4\% increase in the Houston population. This exogenous labor supply shock was likely to make Houston's local labor market thicker by increasing the number of effective participants. Thick local labor markets are associated with lower LACs primarily for two reasons. First, they increase the probability of firms filling vacancies, thus reducing search, selection, and hiring costs (Moretti 2011). Second, they lead to better 
quality employee-firm matches, which are typically associated with longer employee tenures (Jovanovic and Rob 1989), and hence lower labor turnover and LACs (e.g., fewer productivity disruptions). Since Hurricane Katrina induced an exogenous change in LACs as opposed to a change in potential omitted variables, our experiment is designed to capture the impact of labor skills on cash holdings through the LACs channel.

We report the results from our experiment based on Hurricane Katrina in Table 7. Our treatment group consists of firms headquartered in the Houston metropolitan area, while our control group consists of propensity-score-matched firms headquartered in neighboring metropolitan areas that were not affected by Katrina, either directly or indirectly (McIntosh 2008). ${ }^{10}$ We match firms on year, industry, and all covariates. Post is a dummy variable that takes the value of one (zero) for the year following (preceding) Hurricane Katrina. We study a short window around Hurricane Katrina since several studies report a substantial reverse flow of migrants a few years after Katrina (Groen and Polivka 2008, 2010; Paxson and Rouse 2008). Given the unprecedented devastation caused by Hurricane Katrina, the declining economy in New Orleans, even pre-evacuation, and the uncertainty about the pace of recovery (e.g., Vigdor 2008), we assume that Houston-based firms might not have anticipated this significant reverse flow, which, therefore, should not have affected their decision making at the time of the influx of evacuees into Houston.

\footnotetext{
${ }^{10}$ Following McIntosh (2008), our treatment group consists of firms headquartered in the Houston metropolitan area (Houston-Baytown-Sugar Land, TX), whereas our control group consists of propensity-score-matched firms headquartered in other metropolitan areas of Texas and of neighboring states (Arkansas, New Mexico, and Oklahoma, but not Louisiana) that were not affected by Katrina, either directly or indirectly. Metropolitan areas that were in the direct path of the storm and experienced flooding or catastrophic, extensive, or moderate structural damage include Mobile, AL; Baton Rouge and New Orleans-Metairie-Kenner, LA; and GulfportBiloxi and Jackson, MS (Gabe et al. 2005). Indirectly affected areas are those that experienced more than a 1\% gross population increase due to the migration of evacuees, and include Huntsville, AL; Fort Walton BeachCrestview-Destin, Naples-Marco Island, and Pensacola-Ferry Pass-Brent, FL; and Lafayette, Lake Charles, and Monroe, LA.
} 
In Model 1 of Table 7, we run a difference-in-differences specification. The Houston*Post coefficient is negative and significant, indicating that the change in cash holdings from pre- to postKatrina was more negative for firms headquartered in the Houston metropolitan area than for matched firms headquartered in neighboring metropolitan areas. This result is consistent with the expected impact of the increased labor supply on cash holdings through the reduction in LACs, as described above.

Next, we examine the net effect of the Katrina-induced migration on cash holdings by Houston-based firms compared to the control group for different skill levels. We argue that the Katrina-induced migration to Houston should have affected the LACs of highly skilled workers more than those of low-skilled workers for two reasons. First, although the supply of applicants for lowskilled jobs appears to have increased proportionally more than that for highly skilled jobs (Gabe et al. 2005; De Silva et al. 2010), the difference between the proportional increases in the supply of the two types of applicants is likely to have been small (McIntosh 2008). Accordingly, we anticipate that the LACs of both groups of workers would have experienced comparable percentage decreases. Still, given that the LACs of skilled workers are considerably higher in magnitude than those of unskilled workers (see footnote 1), modest and comparable percentage reductions in the LACs of both groups would have led to a much greater decrease in absolute terms in the level of the highly skilled workers' LACs.

Second, the increased thickness of Houston's local labor market post-Katrina is likely to have reduced the probability of an employer not finding a qualified worker, and to have improved the quality of employee-employer matching more for specialized employees than for manual laborers (Moretti 2011; Bleakley and Lin 2012). To the extent that specialized employees (manual laborers) have higher (lower) skills, the Katrina-induced exogenous increase in the labor supply in Houston should have had a more pronounced impact on the LACs of highly skilled workers than low-skilled workers. This argument suggests that our anticipation above of similar reductions (in relative terms) in the LACs of both groups of workers is conservative. That is, it implies that the percentage decrease in highly skilled workers' LACs is likely to have been greater than the percentage decrease in lowskilled workers' LACs. Overall, this line of reasoning further strengthens our conjecture that, 
following Hurricane Katrina, the LACs of skilled workers based in Houston should have experienced a considerably larger decline in absolute terms than those of less skilled workers.

The above arguments both suggest that the negative impact of the Katrina-induced labor migration on the cash holdings of Houston-based firms should be more pronounced for those with a greater share of skilled workers. To test this conjecture, in Model 2 of Table 7, we run a tripledifference (difference-in-difference-in-differences) specification with continuous treatment (De Silva et al. 2010; Acharya, Baghai, and Subramanian 2013). We find that the coefficient on the triple interaction term (LSI*Houston*Post) is negative and highly significant, which is consistent with our prediction.

An alternative explanation of this result could be that the Katrina-induced migration not only reduced LACs but also affected wages and employment in the Houston area, thus reducing Houstonbased firms' wage bill and cash reserves. However, existing evidence of the impact of Hurricane Katrina on labor market outcomes for low- and highly skilled workers in the Houston area is, at best, mixed (McIntosh 2008; De Silva et al. 2010). De Silva et al. (2010), for instance, use establishmentlevel data and find that post-Katrina the wages of firms in low-skill industries in the Houston area experienced a $0.7 \%$ drop relative to firms in high-skill industries when compared to a control group of the same industries in Dallas; this finding suggests that the wage channel is inconsistent with our evidence of a stronger Katrina impact for high-skill firms in Houston. Moreover, the related immigration literature generally shows that migration has a small, if sometimes insignificant, effect on wages and employment in local labor markets (e.g., Card 1990, 2005; Friedberg 2001; Dustmann, Fabbri, and Preston 2005; Basso and Peri 2015). Although it is difficult to completely rule out the wage/employment channel, given the inconclusive and weak evidence in prior research of the impact of migration on wages and employment, we argue that the LACs mechanism is the main mechanism driving our results.

\subsection{Heterogeneity in the Impact of Labor Skills on Cash Holdings}

We next examine potential heterogeneity in the relation between labor skills and cash holdings by conditioning on (a) variations in labor market frictions associated with LACs and (b) 
variations in capital market frictions relating to firms' degree of financial constraint. Specifically, we first study the effect of LSI on cash holdings when firms face exogenous variations in downward (firing) and upward (hiring) adjustment costs. We then examine how the LSI-cash relation is affected by differences in firms' precautionary motive for holding cash.

\subsubsection{Downward versus Upward Adjustment Costs}

\subsubsection{Variation in Firing Costs}

To proxy for differences in a firm's costs of adjusting its labor demand downward, we follow Serfling (2016) and exploit an exogenous variation in firing costs across U.S. states following the state-level recognition of wrongful discharge laws since the 1970s. ${ }^{11}$ WDL measures the strength of WDLs in a state and is constructed by summing three distinct dummy variables for each of the three WDL exceptions, where each dummy is set equal to one if the firm is in a state that has adopted the exception in question and zero otherwise. ${ }^{12}$ Since the passage of WDLs increases firing costs, we expect firms in such states to have greater incentives to minimize labor turnover. Consequently, they have a stronger precautionary motive to build up cash reserves that allow them to cover any future cash flow shortfalls and avoid costly layoffs.

Moreover, we argue that the variation in firing costs due to WDLs should increase with the labor skill level. First, prior research shows that WDLs do not generally apply to temporary employees and in particular unionized workers, who are covered by a collective bargaining agreement (Miles 2000; Autor 2003). In contrast, WDLs typically pertain to full-time or nonunionized employees (Serfling 2016). Based on this argument, and to the extent that low-skilled workers are

\footnotetext{
${ }^{11}$ WDLs are common-law exceptions to the employment-at-will doctrine. They can raise hurdles against firms' wrongful discharge of employees, making it more costly to dismiss workers. There are three exceptions to the employment-at-will doctrine: the public policy exception, the implied contract exception, and the good faith exception. A state can choose to adopt none to all of these exceptions; see Autor, Donohue, and Schwab (2006) for a detailed description of these laws.

${ }^{12}$ In further analysis, we follow Serfling (2016) and focus on the good faith exception, arguably the most effective of the WDL exceptions, and obtain qualitatively similar results.
} 
likely to be unionized while highly skilled workers typically are not, we expect the positive effect of WDLs on firing costs to be more pronounced for firms that rely more on highly skilled employees. Second, empirical evidence shows that WDLs not only matter more for skilled workers, but also these workers are more likely to litigate (Autor, Donohue, and Schwab 2006), thus increasing potential lawsuit costs for their employers. Dertouzos, Holland, and Ebener (1988) study WDL cases in California during 1980-1986 and report that around 54\% of plaintiffs held executive or managerial positions. This finding implies that high-skill firms in states that recognize WDLs are likely to have higher litigation risk than low-skill firms in the same states. Furthermore, WDL trials can be costly for firms since there is a high probability of plaintiffs winning, leading to substantial compensatory damages. For example, Dertouzos, Holland, and Ebener (1988) document that plaintiffs prevailed in $68 \%$ of the WDL trials in California between 1980 and 1986 and were awarded on average $\$ 650,000$, or more than $\$ 1.3$ million in 2012 dollars. Importantly, the earnings and age of the plaintiff explain more than $30 \%$ of the case-to-case variation in these damages. Since earnings and LSI are positively related (Murphy and Welch 1992), we expect firms with high shares of skilled workers to face higher compensatory damages than those with low shares of skilled workers.

Overall, we conjecture that the passage of WDLs should have a significant and positive effect on the firing costs of firms, hence providing them with a greater incentive to hold precautionary cash. Furthermore, this effect should be stronger among high-skill firms because they are more likely to employ a larger share of workers affected by these laws, face higher litigation risk, and subsequently contend with higher lawsuit costs. To capture this effect, we include an interaction term between $W D L$ and $L S I$ and anticipate its coefficient to be positive. In Table 8 , Model 1, we show that $L S I$ has a significantly positive impact on cash holdings, which supports our main hypothesis. Importantly, consistent with our prediction above, the interaction term $\left(L S I^{*} W D L\right)$ is also positive and significant, which indicates a positive marginal effect of WDL on the LSI-cash holdings relation. ${ }^{13}$

\footnotetext{
${ }^{13}$ Although the stand-alone coefficient on WDL is negative and insignificant, the partial effect of WDLs on cash holdings, which is the sum of the coefficient on WDL and that on the interaction term (LSI*WDL) multiplied by
} 


\subsubsection{Variation in Hiring Costs}

Next, we examine the impact of hiring credits (i.e., subsidies paid to employers that hire workers) on the labor skills-cash holdings relation. Our analysis is motivated by Neumark and Grijalva's (forthcoming) evidence that some state subsidy programs can be effective in boosting firm employment. ${ }^{14}$ Although there is great variety in the provision and standards of state-level economic development subsidy programs (Mattera et al. 2011), the majority of these subsidy programs requires job creation as a condition for firms to receive any form of subsidy. We follow Mattera et al.'s (2011) systematic approach to identifying high-quality hiring-credit programs. Their method involves scoring these programs, with a view to ranking them in terms of perceived quality: A higher score assigned to these programs implies higher efficiency in creating high-quality jobs. Using those (state-level) ratings, we construct a hiring credit dummy variable that indicates the existence of high-quality job creation subsidies in the state in which a firm is headquartered. We conjecture that, in states with these high-quality hiring-credit programs, the costs of hiring will be lower, making the precautionary savings motive weaker.

We further predict that the decrease in hiring costs resulting from the availability of highquality subsidy programs will increase in importance with firms' reliance on highly skilled labor. This is because a large number of those subsidy programs has wage requirements, under which firms are either allowed to receive hiring credits only if they have wage thresholds in place or the level of credits they receive depends on wage thresholds. These thresholds vary from minimum wage to well

$L S I$, is positive. Moreover, in further regression analysis (untabulated), we find the coefficient on WDL to be significantly positive when the interaction term $(L S I * W D L)$ is excluded from the model. These results are consistent with our conjecture regarding the impact of WDLs on cash holdings and recent research on the impact of employment protection laws on financial leverage (Simintzi, Vig, and Volpin 2015; Serfling 2016).

${ }^{14}$ While earlier evidence shows that hiring credits are less effective than worker subsidies (e.g., Hamersma 2008,2011 ), recent studies argue that broad-based subsidy programs can help spur job creation in the short run, especially after periods of severe recession; see Neumark (2013) for a review. Recent evidence also suggests the effectiveness of hiring credits in France (Cahuc, Carcillo, and Barbanchon 2015). 
above average state or sector wages, which, for some programs, reach $300 \%$ of mean wages. Given the significantly positive correlation between wages and worker skill level (Murphy and Welch 1992), subsidy programs requiring high wage thresholds are likely to target job creation in firms that require skilled labor. Importantly, such programs are given a higher score according to Mattera et al.'s (2011) rating system. In other words, a program that targets the creation of skilled jobs (i.e., has higher wage thresholds) receives a higher score. We therefore anticipate that high-quality hiring-credit programs decrease hiring costs more for firms with greater reliance on skilled workers. To capture this effect, we create an interaction term between the hiring credits variable and $L S I$. We expect the coefficient on this interaction term to be negative. The regression results in Model 2 of Table 8 provide strong evidence in support of our prediction. The coefficient on the interaction term between hiring credits and labor skills is indeed negative and highly significant. ${ }^{15}$

Finally, in Model 3 of Table 8, we include all additional regressors examined in Models 1 and 2 above (i.e., variables proxying for differences in firing costs as well as those proxying for differences in hiring costs). We find that after controlling for variation in both WDLs and hiring credits, LSI remains significantly positive, which is consistent with our argument that labor skills are an important proxy for all components of LACs (Oi 1962; Hamermesh and Pfann 1996) and suggests that the impact of $L S I$ on cash is above and beyond that of firing and hiring costs. More importantly, we continue to document strong evidence that the LSI-cash holdings relation varies with the strength of labor protection and the quality of hiring-credit programs in the state in which the firm is headquartered. Taken together with the results in Models 1 and 2, these findings suggest that the impact of labor skills on cash holdings is more important in labor markets with higher downward adjustment costs and less pronounced in labor markets with lower upward adjustment costs.

\footnotetext{
${ }^{15}$ The partial effect of Hiring credits on cash holdings is negative as the coefficient on the interaction term, LSI*Hiring credits, is negative and highly significant. When we exclude this interaction term, the stand-alone coefficient on Hiring credits becomes significantly negative. These results are consistent with the prediction that hiring credits can reduce the costs of hiring and lower the precautionary savings motive.
} 


\subsubsection{The Effect of Financial Constraints}

The precautionary motive for holding cash is most relevant for financially constrained firms (Almeida, Campello, and Weisbach 2004, 2011; Han and Qiu 2007) since the use of cash as a buffer to avoid costly labor adjustments in response to cash flow shocks is more important when financial constraints are binding. We thus predict that the positive relation between labor skills and cash holdings is more pronounced when firms face greater frictions in capital markets. To test this prediction, we split our sample into constrained and unconstrained firms. We measure the degree of financial constraints using three different proxies: the size and age (SA) index (Hadlock and Pierce 2010), the Kaplan and Zingales (KZ) index (Kaplan and Zingales 1997), and the Whited and Wu (WW) index (Whited and Wu 2006). We define firms with above-median scores on the SA, KZ, and WW indexes as constrained and those with below-median scores as unconstrained.

Table 9 shows how the relation between firms' reliance on skilled labor and their cash holdings varies with their degree of financial constraint. Models 1 and 2 report the results for the two subsamples of constrained and unconstrained firms according to the SA index. In line with the precautionary savings motive, the coefficient on LSI is higher for constrained firms $(0.093)$ than for unconstrained firms $(0.061)$; the difference is statistically significant at the $1 \%$ level. Models 3 through 6 reveal similar patterns when we proxy for financial constraints using the KZ or WW index. In sum, our findings are consistent with the prediction that the positive impact of LSI on cash holdings is more pronounced for constrained firms.

\section{Robustness Checks and Additional Analyses}

\subsection{Labor Adjustment Costs or Intangible Capital?}

Firms relying on skilled labor may also have substantial "intangible capital." Specifically, these firms may have important intangible assets created by R\&D expenditures as well as human and organizational capital knowledge embedded in their skilled workers (Falato, Kadyrzhanova, and Sim 2013; Klasa et al. 2015). Consequently, cash holdings may be positively related to LSI through the intangible capital channel. For instance, to the extent that high-labor-skill firms wish to protect their valuable intangible assets, and given uncertainty in the future cash flows generated by such assets, 
these firms may have a strong precautionary motive for holding cash. While this prediction is consistent with our central hypothesis regarding the direction of the relation between LSI and cash holdings, it is based on a mechanism that operates through the protection of intangible capital rather than LACs. Although there is no indisputable way of disentangling the two channels, since intangible capital and labor skills should be highly correlated, we conduct additional tests to show that the impact of skilled labor on cash holdings is above and beyond the effect of intangible capital.

First, we examine a subsample of firms that have zero R\&D expenditures. We argue that firms reporting zero R\&D must have fewer intangible assets and, as a result, less incentive to hold precautionary cash to protect such assets. By focusing on firms for which the risk of losing intangible assets is relatively low, we can isolate the effect of labor skills on cash holdings that is directly caused by LACs considerations. We note that, in our PSM analysis presented above, we report results from a matched sample of high- versus low-skill zero-R\&D firms that are consistent with our conjectures on the impact of skilled labor on cash holdings. In addition to these results, in Model 1 of Table 10, we report the findings for the subsample of zero-R\&D firms using our main (unmatched) sample. We find the coefficient on LSI to be significant and positive at $1 \%$ for these firms, which supports our central argument based on the LACs mechanism. More importantly, in Model 4, we investigate a subsample of firms with zero R\&D expenditures and a high share of skilled labor. Using this restricted subsample, we contend that a significant difference between the cash balances of high-skill firms and those employing less highly skilled labor should be mainly due to variation in the LACs associated with these skill levels. In line with this prediction, we find that the coefficient on LSI remains positive and significant for this restricted subsample.

A potential limitation of the above analysis is that investments in $R \& D$ are not an encompassing measure of intangible capital. To address this concern, we follow the economics literature (Lev and Radhakrishnan 2005; Corrado, Hulten, and Sichel 2009; Corrado and Hulten 2010) and recent finance research (Eisfeldt and Papanikolaou 2013; Falato, Kadyrzhanova, and Sim 2013; Peters and Taylor 2017) and employ a more comprehensive measure of intangible capital. In particular, we consider both internally created and externally purchased intangible capital as in Peters and Taylor (2017). We measure the stock of internally created intangible capital as the sum of 
knowledge capital and organizational capital. We estimate the stock of knowledge capital by accumulating past R\&D spending using the perpetual inventory method. The stock of organizational capital is estimated by accumulating a fraction of past selling, general, and administrative (SG\&A) expenses using the same method. ${ }^{16}$ Following Peters and Taylor (2017), we use the balance sheet item "Intangible Assets" to measure externally purchased intangible capital.

Similar to our earlier analysis for zero-R\&D firms, in the remainder of Table 10, we present results for the whole sample (Models 2-3) and for the subsample of high-skill firms (Models 5-6). We perform two tests. First, in Model 2, we check the robustness of our results to the inclusion of the comprehensive measure of intangible capital as an additional control. We find that intangible capital is positively and significantly related to cash holdings, which is in line with Falato, Kadyrzhanova, and Sim (2013). However, controlling for intangible capital does not affect either the statistical or the economic significance of the coefficient on LSI. Second, in Model 3, we examine a subsample of firms that have low intangible capital (bottom 30th percentile). We find the coefficient on LSI to be positive and significant at $1 \%$ for these firms, which supports our central argument based on the LACs channel. The results remain qualitatively unchanged in Models 5-6 when we rerun the regressions for the subsample of high-skill firms.

Overall, the above tests show that the positive relationship between LSI and cash holdings continues to hold when we control for a comprehensive measure of intangible capital or concentrate on firms with potentially limited intangible capital. We conclude that our results remain consistent with a LACs explanation and thus are unlikely to be driven only by the intangible capital channel.

\subsection{Alternative Measures of Cash Holdings and Labor Skills}

While the cash-to-total assets ratio is the most traditional measure of cash holdings, some studies use alternative definitions (e.g., Opler et al. 1999; Klasa, Maxwell, and Ortiz-Molina 2009).

\footnotetext{
${ }^{16}$ Our approach of using the perpetual inventory method to capitalize R\&D and SG\&A expenses is similar to that in recent papers (Eisfeldt and Papanikolaou 2013; Falato, Kadyrzhanova, and Sim 2013; Peters and Taylor 2017). A similar method is used by the Bureau of Economic Analysis to capitalize R\&D expenses.
} 
To establish the robustness of our results, we replicate our main regressions using two alternative measures of cash holdings, namely, the natural logarithm of cash and short-term investments, scaled by book assets net of cash and short-term investments, and the natural logarithm of the ratio of cash and short-term investments to total sales. Untabulated results confirm that the coefficient on LSI is positive and highly significant.

We also consider an alternative measure of labor skills, which we construct similarly to our original LSI. The only difference is that, instead of using the O*NET skill zones to proxy for the level of skill of an occupation $\left(Z_{j}\right.$ in the original $\left.L S I\right)$, we use the occupation's average hourly wage. We use the OES dataset to collect data on wages at the occupational level. In untabulated analysis, we rerun our baseline regression and find that the coefficient on LSI remains positive and highly significant. Overall, we conclude that our findings are robust to alternative definitions of cash holdings and LSI.

\subsection{Further Tests}

We conduct a series of additional tests that showcase the robustness of our main result and offer more insights on the relations between skilled labor and cash holdings as well as a related corporate policy, namely, financial leverage. To conserve space, we report and discuss the results from these tests in the Internet Appendix.

First, we control for several important determinants of cash holdings identified by recent papers, which may also be related to our measure of labor skills. In doing so, we further mitigate the potential omitted variable bias and rule out alternative explanations for the effect of labor skills on cash holdings. The results in Table IA.1 of the Internet Appendix show that the impact of skilled labor on cash holdings remains positive and significant after controlling for the industry unionization rate (Klasa, Maxwell, and Ortiz-Molina 2009), product market characteristics, such as industry concentration and product market fluidity (Haushalter, Klasa, and Maxwell 2007; Hoberg, Phillips, and Prabhala 2014), refinancing risk (Harford, Klasa, and Maxwell 2014), and foreign tax burden (Foley et al. 2007). Second, we examine the impacts of labor skills on the cash flow sensitivity of cash (Almeida, Campello, and Weisbach 2004) and the market value of cash (Faulkender and Wang 2006). The results in Tables IA. 2 and IA. 3 of the Internet Appendix suggest that firms with a higher share of 
skilled labor have a higher propensity to save cash from their cash flows and enjoy a higher market value of cash, which further highlights the importance of cash reserves for high-skill firms. Finally, we test the proposition that high-skill firms, which face significant LACs, should adopt conservative financial policies by maintaining not only high cash holdings but also low financial leverage. The results reported in Table IA.4 are consistent with this conjecture and recent evidence on the impact of firing costs on capital structure (e.g., Simintzi, Vig, and Volpin 2015; Serfling 2016).

\section{Conclusion}

We investigate the impact of a firm's reliance on skilled labor on its cash management policy. Firms differ in their degree of reliance on skilled workers and face substantial LACs that increase with their workers' skill level. This labor market friction incentivizes firms to optimally keep their employment stable. However, following an optimal labor retention policy reduces firms' ability to adjust labor demand in response to cash flow shocks, exposing them to future cash flow shortfalls. Therefore, we hypothesize that firms with a high share of skilled workers have a precautionary motive to hold cash reserves, which safeguard them against unexpected cash flow fluctuations while allowing them to keep labor turnover optimally low.

In line with this hypothesis, we document novel evidence that our labor skill index, measured at the industry level, has a positive and significant impact on firms' cash holdings. Furthermore, the impact of labor skills on cash holdings is robust to a variety of model specifications, alternative measures of the variables of interest, and tests controlling for alternative explanations. To mitigate endogeneity concerns, we employ three different strategies based on subsamples of relatively similar industries and firms, PSM, and a quasi-natural experiment associated with exogenous variation in LACs. While it is hard to fully rule out endogeneity, taken together, these tests provide consistent results, all pointing to a causal effect of labor skills on cash holdings.

We next examine variation in the LSI-cash holdings relation. We find the impact of labor skills on cash to be stronger in labor markets with higher downward adjustment costs and weaker in labor markets with lower upward adjustment costs. We also observe that the positive relation between LSI and cash continues to hold after controlling for exogenous differences in hiring and firing costs, 
suggesting that the effect of LSI, as a broader measure of LACs, on cash is above and beyond that of individual proxies for LACs (i.e., employment protection laws or hiring credits). Furthermore, consistent with the precautionary savings motive, we find the effect of LSI on cash holdings to be stronger for firms that are financially constrained. Additional analysis shows that firms that rely more on skilled labor have a higher marginal value of cash and tend to save more precautionary cash from their cash flows.

Finally, we address a concern that our results may be driven primarily by the intangible capital channel rather than LACs; under this alternative channel, for example, high-labor-skill firms would build up cash reserves mainly to protect valuable intangible assets rather than skilled labor. Although the two channels are not mutually exclusive, our analysis shows that the impact of labor skills on cash holdings is consistent with the LACs mechanism and not simply due to the intangible capital channel.

Overall, we show that high-skill firms respond to high LACs by adopting conservative cash policies. Our findings suggest that labor heterogeneity, and in particular the skill level of workers, is an important determinant of corporate cash holdings. 


\section{References}

Abadie, A., and G. Imbens. 2006. Large sample properties of matching estimators for average treatment effects. Econometrica 68:1365-406.

Acharya, V., H. Almeida, and M. Campello. 2013. Aggregate risk and the choice between cash and lines of credit. Journal of Finance 68:2059-116.

Acharya, V., R. Baghai, and K. Subramanian. 2013. Labor laws and innovation. Journal of Law and Economics 56:997-1037.

Agrawal, A., and D. Matsa. 2013. Labor unemployment risk and corporate financing decisions. Journal of Financial Economics 108:449-70.

Almeida, H., M. Campello, and M. Weisbach. 2004. The cash flow sensitivity of cash. Journal of Finance 59:1777-804.

- 2011. Corporate financial and investment policies when future financing is not frictionless. Journal of Corporate Finance 17:675-93.

Almeida, H., M. Campello, I. Cunha, and M. Weisbach. 2014. Corporate liquidity management: A conceptual framework and survey. Annual Review of Financial Economics 6:135-62.

Autor, D. 2003. Outsourcing at will: The contribution of unjust dismissal doctrine to the growth of employment outsourcing. Journal of Labor Economics 21:1-42.

Autor, D., J. Donohue III, and S. Schwab. 2006. The costs of wrongful-discharge laws. Review of Economics and Statistics 88:211-31.

Azar, J., J.-F. Cagy, and M. Schmalz. 2016. Can changes in the cost of carry explain the dynamics of corporate cash holdings? Review of Financial Studies 29:2194-240.

Bacchetta, P., K. Benhima, and C. Poilly. 2015. Corporate cash and employment. Working Paper, University of Lausanne.

Bae, K., J. Kang, and J. Wang. 2011. Employee treatment and firm leverage: A test of the stakeholder theory of capital structure. Journal of Financial Economics 100:130-53.

Baghai, R., R. Silva, V. Thell, and V. Vig. 2015. Talent in distressed firms: Investigating the labor costs of financial distress. Working Paper, Stockholm School of Economics. 
Basso, G., and G. Peri. 2015. The association between immigration and labor market outcomes in the United States. Working Paper, Institute for the Study of Labor (IZA).

Bates, T., K. Kahle, and R. Stulz. 2009. Why do U.S. firms hold so much more cash than they used to? Journal of Finance 64:1985-2021.

Belo, F., X. Lin, J. Li, and X. Zhao. Forthcoming. Labor-force heterogeneity and asset prices: The importance of skilled labor. Review of Financial Studies.

Berk, J., R. Stanton, and J. Zechner. 2010. Human capital, bankruptcy, and capital structure. Journal of Finance 65:891-926.

Blatter, M., S. Muehlemann, and S. Schenker. 2012. The costs of hiring skilled workers. European Economic Review 56:20-35.

Blatter, M., S. Muehlemann, S. Schenker, and S. Wolter 2016. Hiring costs for skilled workers and the supply of firm-provided training. Oxford Economic Papers 68:238-57.

Bleakley, H., and J. Lin. 2012. Thick-market effects and churning in the labor market: Evidence from US cities. Journal of Urban Economics 72:87-103.

Boeri, T., P. Garibaldi, and E. Moen. 2014. Financial constraints in search equilibrium. Working Paper, Centre for Economic Performance.

Brown, J., and D. Matsa. 2016. Boarding a sinking ship? An investigation of job applications to distressed firms. Journal of Finance 71:507-50.

Brown, J., and B. Petersen. 2011. Cash holdings and R\&D smoothing. Journal of Corporate Finance 17:694-709.

Cahuc, P., S. Carcillo, and T. Barbanchon. 2015. The effectiveness of hiring credits. Working paper, Institute for the Study of Labor (IZA).

Card, D. 1990. The impact of the Mariel boatlift on the Miami labor market. Industrial and Labor Relations Review 43:245-57.

Card, D. 2005. Is the new immigration really so bad? Economic Journal 115: 300-23.

Corrado, C., C. Hulten, and D. Sichel. 2009. Intangible capital and U.S. economic growth. Review of Income and Wealth 55:661-85. 
Corrado, C., and C. Hulten. 2010. How do you measure a technological revolution? American Economic Review 100:99-104.

De Silva, D., R. McComb, Y. Moh, A. Schiller, and A. Vargas. 2010. The effect of migration on wages: Evidence from a natural experiment. American Economic Review 100:321-26.

Dertouzos, J., E. Holland, and P. Ebener. 1988. The legal and economic consequences of wrongful termination. Rand Corporation document R-3602-ICJ. Santa Monica: Rand Corporation.

Dixit, A. 1997. Investment and employment dynamics in the short run and the long run. Oxford Economic Papers 49:1-20.

Dolfin, S. 2006. An examination of firms' employment costs. Applied Economics 38:861-78.

Donangelo, A. 2014. Labor mobility: Implications for asset pricing. Journal of Finance 69:1321-46.

Dube, A., E. Freeman, and M. Reich. 2010. Employee replacement costs. Working Paper, University of California, Berkeley.

Dustmann, C., F. Fabbri, and I. Preston. 2005. The impact of immigration on the British labour market. Economic Journal 115:324-41.

Eisfeldt, A., and D. Papanikolaou. 2013. Organization capital and the cross-section of expected returns. Journal of Finance 68:1365-406.

Falato, A., D. Kadyrzhanova, and J. Sim. 2013. Rising intangible capital, shrinking debt capacity, and the U.S. corporate savings glut. Working Paper, Federal Reserve Board.

Farber, H., and K. Hallock. 2009. The changing relationship between job loss announcements and stock prices: 1970-1999. Labour Economics 16:1-11.

Faulkender, M., and R. Wang. 2006. Corporate financial policy and the value of cash. Journal of Finance 61:1957-90.

Foley, F., J. Hartzell, S. Titman, and G. Twite. 2007. Why do firms hold so much cash? A tax-based explanation. Journal of Financial Economics 86:579-607.

Frésard, L. 2010. Financial strength and product market behavior: The real effects of corporate cash holdings. Journal of Finance 65:1097-122.

Friedberg, R. 2001. The impact of mass migration on the Israeli labor market. Quarterly Journal of Economics 116:1373-408. 
Gabe, T., G. Falk, M. McCarty, and V. Mason. 2005. Hurricane Katrina: Social-demographic characteristics of impacted areas. Congressional Research Service Report for Congress.

Groen, J., and A. Polivka. 2008. The effect of Hurricane Katrina on the labor market outcomes of evacuees. American Economic Review 98:43-8.

- 2010. Going home after Hurricane Katrina: Determinants of return migration and changes in affected areas. Demography 47:821-44.

Hadlock, C., and J. Pierce. 2010. New evidence on measuring financial constraints: Moving beyond the KZ index. Review of Financial Studies 23:1909-40.

Hamermesh, D. 1989. Labor demand and the structure of adjustment costs.American Economic Review 79:674-89.

1995. Labor demand and the source of adjustment costs. Economic Journal 105:620-34.

Hamermesh, D., and G. Pfann. 1996. Adjustment costs in factor demand. Journal of Economic Literature 34:1264-92.

Hamersma, S. 2008. The effects of an employer subsidy on employment outcomes: A study of the Work Opportunity and Welfare-to-Work Tax Credits. Journal of Policy Analysis and Management 27:498-520.

- 2011. Why don't eligible firms claim hiring subsidies? The role of job duration. Economic Inquiry 49:916-34.

Han, S., and J. Qiu. 2007. Corporate precautionary cash holdings. Journal of Corporate Finance $13: 43-57$.

Harford, J., S. Klasa, and W. Maxwell. 2014. Refinancing risk and cash holdings. Journal of Finance 69:975-1012.

Haushalter, D., S. Klasa, and W. Maxwell. 2007. The influence of product market dynamics on a firm's cash holdings and hedging behavior. Journal of Financial Economics 84:797-825.

Hoberg, G., G. Phillips, and N. Prabhala. 2014. Product market threats, payouts, and financial flexibility. Journal of Finance 69:293-324.

Jovanovic, B., and R. Rob. 1989. The growth and diffusion of knowledge. Review of Economic Studies 56:569-82. 
Kaplan, S., and L. Zingales. 1997. Do investment-cash flow sensitivities provide useful measures of financing constraints? Quarterly Journal of Economics 112:169-215.

Karabarbounis, L., and B. Neiman. 2012. Declining labor shares and the global rise of corporate saving. Working Paper, University of Chicago.

Kim, H. 2015. How does labor market size affect firm capital structure? Evidence from large plant openings. Working Paper, Cornell University.

Klasa, S., W. Maxwell, and H. Ortiz-Molina. 2009. The strategic use of corporate cash holdings in collective bargaining with labor unions. Journal of Financial Economics 92:421-42.

Klasa, S., H. Ortiz-Molina, M. Serfling, and S. Srinivasan. 2015. Protection of trade secrets and capital structure decisions. Working Paper, University of Arizona.

Kuzmina, O. 2013. Operating flexibility and capital structure: Evidence from a natural experiment. Working Paper, New Economic School.

Lev, B., and S. Radhakrishnan. 2005. The valuation of organization capital, in Carol Corrado, John Haltiwanger, and Dan Sichel, eds.: Measuring Capital in the New Economy, (National Bureau of Economic Research, Inc, Cambridge, MA).

McIntosh, M. 2008. Measuring the labor market impacts of Hurricane Katrina migration: Evidence from Houston, Texas. American Economic Review 98:54-7.

Manning, A. 2003. Monopsony in motion. Princeton, NJ: Princeton University Press.

- 2006. A generalised model of monopsony. Economic Journal 116:84-100.

Matsa, D. 2010. Capital structure as a strategic variable: Evidence from collective bargaining. Journal of Finance 65:1197-232.

Mattera, P., T. Cafcas, L. McIlvaine, A. Seifter, and K. Tarczynska. 2011. Money for something: Job creation and job quality standards in state economic development subsidy programs. Available at http://www.goodjobsfirst.org/sites/default/files/docs/pdf/moneyforsomething.pdf.

Milanez, H. 2012. The human capital costs of financial constraint. Working Paper, Harvard Business School.

Miles, T. 2000. Common law exceptions to employment at will and U.S. labor markets. Journal of Law, Economics, \& Organization 16:74-101. 
Moretti, E. 2011. Local labor markets. Handbook of Labor Economics 4B:1237-313.

Murphy, K., and F. Welch. 1992. The structure of wages. Quarterly Journal of Economics 107:285326.

Neumark, D. 2013. Spurring job creation in response to severe recessions: Reconsidering hiring credits. Journal of Policy Analysis and Management 32:142-71.

Neumark, D., and D. Grijalva. Forthcoming. The employment effects of state hiring credits. Industrial and Labor Relations Review.

Ochoa, M. 2013. Volatility, labor heterogeneity and asset prices. Working Paper, Federal Reserve Board, Washington.

Oi, W. 1962. Labor as a quasi-fixed factor. Journal of Political Economy 70:538-55.

Opler, T., L. Pinkowitz, R. Stulz, and R. Williamson. 1999. The determinants and implications of corporate cash holdings. Journal of Financial Economics 52:3-46.

Paxson, C., and C. Rouse. 2008. Returning to New Orleans after Hurricane Katrina. American Economic Review 98:38-42.

Peters, R., and L. Taylor. 2017. Intangible capital and the investment-q relation. Journal of Financial Economics 123:251-72.

Pfann, G., and F. Palm. 1993. Asymmetric adjustment costs in non-linear labour demand models for the Netherlands and U.K. manufacturing sectors. Review of Economic Studies 60:397-412.

Schmalz, M. 2015. Unionization, cash, and leverage. Working Paper, University of Michigan.

Serfling, M. 2016. Firing costs and capital structure decisions. Journal of Finance 71:2239-86.

Shapiro, M. 1986. The dynamic demand for capital and labor. Quarterly Journal of Economics $101: 513-42$.

Simintzi, E., V. Vig, and P. Volpin. 2015. Labor protection and leverage. Review of Financial Studies 28:561-91.

Vigdor, J. 2008. The economic aftermath of Hurricane Katrina. Journal of Economic Perspectives 22:135-54.

Whited, T., and G. Wu. 2006. Financial constraints risk. Review of Financial Studies 19:531-59. 


\section{Table 1. Labor Skill Levels across Different Industries}

This table presents examples of industries with the least and most reliance on skilled labor. Our sample consists of 68,057 firm-year observations covering the period 1999-2012. We measure a firm's reliance on skilled labor using the following index: $L S I_{i}=\sum_{j=1}^{O}\left(\frac{E_{j i}}{E_{i}} * Z_{j}\right)$, where $E_{j i}$ is the number of employees in industry $i$ working in occupation $j, E_{i}$ is the total number of employees in industry $i$, and $O$ is the total number of occupations in industry $i$. Finally, $Z_{j}$ is the U.S. Department of Labor's $O^{*}$ NET program classification of occupations based on skill level; this program classifies occupations into five job zones, ranging from job zone 1, which includes occupations that require little or no skill, to job zone 5, which consists of occupations that require extensive skills. By construction, LSI ranges from 1 to 5: low (high) values imply that the majority of workers in the industry require few (extensive) skills in order to perform their jobs.

\begin{tabular}{ll}
\hline Industry & Reliance on Skilled Labor Index (LSI) \\
\hline Full sample & 2.471 \\
Least Reliance on Skilled Labor: & \\
Gasoline stations & 1.281 \\
Restaurants and other eating places & 1.306 \\
Services to buildings & 1.371 \\
Amusement parks and arcades & 1.448 \\
Grocery stores & 1.462 \\
Department stores & 1.637 \\
Footwear manufacturing & 1.735 \\
Most Reliance on Skilled Labor: & \\
Legal services & 3.134 \\
Architectural, engineering, and related services & 3.184 \\
Colleges, universities, and professional schools & 3.306 \\
Offices of health practitioners & 3.226 \\
Scientific R\&D services & 3.194 \\
Electronic and precision equipment & \\
Software publishers & 3.187 \\
Accounting and tax preparation services & \\
Management and technical consulting services & \\
\hline
\end{tabular}




\section{Table 2. Summary Statistics}

This table reports summary statistics for the dependent variable (cash holdings), our key variable (LSI), and a set of control variables. Our sample consists of 68,057 firm-year observations covering the period 1999-2012. Cash holdings are the ratio of cash and short-term investments (che) to total assets (at). The reliance on skilled labor is defined in Table 1. Cash flow is earnings after interest, dividends, and tax but before depreciation (oibdp - xint - txt - dvc), scaled by the book value of total assets (at). Net working capital is measured as working capital (wcap) minus cash (che), scaled by total assets (at). Capital expenditures is the ratio of capital expenditures (capx) to total assets (at). Leverage is long-term debt (dltt) plus debt in current liabilities (dlc), scaled by total assets (at). Acquisitions are defined as the ratio of acquisitions (aqc) to total assets (at). The market-to-book ratio is defined as the book value of assets (at) plus the market value of common equity (prcc_f * csho) minus the book value of common equity (ceq), scaled by the book value of assets (at). Size is measured as the logarithm of the book value of assets (at) in 1999 dollars. To measure industry cash flow volatility, we calculate for each firm-year the standard deviation of (firm-level) cash flow to assets for the previous five years. Industry cash flow volatility (Ind. CF volatility) is then calculated as the average of the firm cash flow standard deviations for each industry, classified by two-digit SIC codes. $R \& D$ expenditures is the ratio of R\&D expenses (xrd) to net sales (sale), and is set equal to zero when R\&D expenses (xrd) are missing. Dividend dummy is a dummy variable set equal to one in years in which a firm pays common dividends (dvc), and zero otherwise.

\begin{tabular}{lccccc}
\hline Variable & Mean & Q1 & Median & Q4 & Std. Dev. \\
\hline $\begin{array}{l}\text { Dependent variable: } \\
\text { Cash holdings }\end{array}$ & 0.198 & 0.029 & 0.105 & 0.290 & 0.228 \\
Variable of interest: & & & & & \\
LSI & 2.471 & 2.145 & 2.443 & 2.812 & 0.501 \\
Control variables: & & & & & \\
Cash flow & -0.190 & -0.072 & 0.051 & 0.101 & 0.979 \\
Net working capital & -0.148 & -0.087 & 0.017 & 0.144 & 1.109 \\
Capital expenditures & 0.060 & 0.015 & 0.033 & 0.071 & 0.077 \\
Leverage & 0.320 & 0.026 & 0.191 & 0.372 & 0.620 \\
Acquisitions & 0.022 & 0.000 & 0.000 & 0.006 & 0.060 \\
Market-to-book & 3.043 & 1.088 & 1.512 & 2.493 & 6.034 \\
Size & 4.940 & 3.279 & 5.008 & 6.668 & 2.531 \\
Ind. CF volatility & 1.345 & 0.180 & 0.835 & 1.689 & 1.746 \\
R\&D expenditures & 0.491 & 0.000 & 0.000 & 0.082 & 2.694 \\
Dividend dummy & 0.252 & 0.000 & 0.000 & 1.000 & 0.434 \\
\hline
\end{tabular}




\section{Table 3. Univariate Analysis: Firm Characteristics across Different Labor Skill Levels}

This table reports the mean firm characteristics for the full sample and two subsamples of firms according to their degree of reliance on skilled labor (i.e., firms with above- and below-median LSI scores). The dependent and control variables are defined in Table 2. The sample period is 1999-2012. $N$ denotes the number of observations. $* * * * *$, and $*$ denote statistical significance at the $1 \%, 5 \%$, and $10 \%$ levels, respectively.

\begin{tabular}{|c|c|c|c|c|c|}
\hline & $\begin{array}{c}\text { Overall } \\
\text { sample } \\
(\mathrm{N}=68,057) \\
(1)\end{array}$ & $\begin{array}{c}\text { Firms with } \\
\text { above-median } \\
\text { LSI } \\
(\mathrm{N}=34,017) \\
(2)\end{array}$ & $\begin{array}{c}\text { Firms with } \\
\text { below-median } \\
\text { LSI } \\
(\mathrm{N}=34,024) \\
(3)\end{array}$ & $\begin{array}{c}\text { Test of } \\
\text { difference } \\
\text { in means } \\
\text { (standard errors } \\
\text { without } \\
\text { clustering) } \\
\text { (4) }\end{array}$ & $\begin{array}{c}\text { Test of } \\
\text { difference } \\
\text { in means } \\
\text { (standard errors } \\
\text { clustered at } \\
\text { industry level) } \\
\text { (5) }\end{array}$ \\
\hline \multicolumn{6}{|l|}{ Dependent variable: } \\
\hline Cash holdings & 0.198 & 0.261 & 0.136 & $* * *$ & $* * *$ \\
\hline \multicolumn{6}{|l|}{ Control variables: } \\
\hline Cash flow & -0.190 & -0.271 & -0.109 & $* * *$ & $* * *$ \\
\hline Net working capital & -0.148 & -0.208 & -0.088 & $* * *$ & $* * *$ \\
\hline Capital expenditures & 0.060 & 0.056 & 0.063 & $* * *$ & \\
\hline Leverage & 0.320 & 0.311 & 0.329 & $* * *$ & \\
\hline Acquisitions & 0.022 & 0.022 & 0.021 & $* * *$ & \\
\hline Market-to-book & 3.043 & 3.529 & 2.553 & $* * *$ & $* * *$ \\
\hline Size & 4.940 & 4.559 & 5.322 & $* * *$ & $* * *$ \\
\hline Industry CF volatility & 1.345 & 1.590 & 1.110 & $* * *$ & \\
\hline R\&D expenditures & 0.491 & 0.841 & 0.142 & $* * *$ & \\
\hline Dividend dummy & 0.252 & 0.175 & 0.329 & $* * *$ & $* * *$ \\
\hline
\end{tabular}




\section{Table 4. The Relation between Cash Holdings and Skilled Labor}

This table reports regression results regarding the impact of firms' reliance on skilled labor on their cash holdings. In Model 1, we regress cash holdings on the control variables. In Model 2, we include LSI as an additional explanatory variable. In Model 3, we perform a cross-sectional regression using the firm-specific time-series means of the variables. Model 4 is similar to Model 3 except that we use industry averages instead of firm averages. Models 5 and 6 control for firm and industry (three-digit SIC codes) fixed effects. All regressions include year dummies except for Models 3 and 4. All variables are defined in Tables 1 and 2. The $p$-values in parentheses are based on robust standard errors clustered at the industry level, except in Model 4 , where the $p$ values are based on non-clustered heteroskedasticity-robust standard errors. $* * *, * *$, and $*$ denote statistical significance at the $1 \%, 5 \%$, and $10 \%$ levels, respectively.

\begin{tabular}{|c|c|c|c|c|c|c|}
\hline \multirow[b]{2}{*}{ Variables } & \multicolumn{2}{|c|}{ OLS } & \multirow{2}{*}{$\begin{array}{l}\text { Across } \\
\text { firm } \\
(3)\end{array}$} & \multirow{2}{*}{$\begin{array}{c}\text { Across } \\
\text { industry } \\
(4)\end{array}$} & \multicolumn{2}{|c|}{ Fixed effects } \\
\hline & (1) & (2) & & & $(5)$ & $(6)$ \\
\hline LSI & & $\begin{array}{l}0.084 * * * \\
(0.00)\end{array}$ & $\begin{array}{l}0.095 * * * \\
(0.00)\end{array}$ & $\begin{array}{l}0.028 * * * \\
(0.01)\end{array}$ & $\begin{array}{l}0.013 * * * \\
(0.00)\end{array}$ & $\begin{array}{l}0.024 * * * \\
(0.00)\end{array}$ \\
\hline Cash flow & $\begin{array}{l}0.008^{* *} \\
(0.02)\end{array}$ & $\begin{array}{l}0.009 * * * \\
(0.01)\end{array}$ & $\begin{array}{l}0.004 \\
(0.37)\end{array}$ & $\begin{array}{l}0.041 \\
(0.35)\end{array}$ & $\begin{array}{l}0.017 * * * \\
(0.00)\end{array}$ & $\begin{array}{l}0.008 * * * \\
(0.00)\end{array}$ \\
\hline Net working capital & $\begin{array}{l}-0.036^{* * *} \\
(0.00)\end{array}$ & $\begin{array}{l}-0.033 * * * \\
(0.00)\end{array}$ & $\begin{array}{l}-0.030^{* * *} \\
(0.00)\end{array}$ & $\begin{array}{l}-0.120^{* * *} \\
(0.01)\end{array}$ & $\begin{array}{l}-0.013^{* * *} \\
(0.00)\end{array}$ & $\begin{array}{l}-0.027 * * * \\
(0.00)\end{array}$ \\
\hline Capital expenditures & $\begin{array}{l}-0.484 * * * \\
(0.00)\end{array}$ & $\begin{array}{l}-0.447 * * * \\
(0.00)\end{array}$ & $\begin{array}{l}-0.507^{* * *} \\
(0.00)\end{array}$ & $\begin{array}{l}-0.081 \\
(0.59)\end{array}$ & $\begin{array}{l}-0.212 * * * \\
(0.00)\end{array}$ & $\begin{array}{l}-0.315^{* * *} \\
(0.00)\end{array}$ \\
\hline Leverage & $\begin{array}{l}-0.146^{* * *} \\
(0.00)\end{array}$ & $\begin{array}{l}-0.136^{* * *} \\
(0.00)\end{array}$ & $\begin{array}{l}-0.141 * * * \\
(0.00)\end{array}$ & $\begin{array}{l}-0.290 * * * \\
(0.00)\end{array}$ & $\begin{array}{l}-0.055^{* * *} \\
(0.00)\end{array}$ & $\begin{array}{l}-0.117 * * * \\
(0.00)\end{array}$ \\
\hline Acquisitions & $\begin{array}{l}-0.369 * * * \\
(0.00)\end{array}$ & $\begin{array}{l}-0.398^{* * * *} \\
(0.00)\end{array}$ & $\begin{array}{l}-0.684 * * * \\
(0.00)\end{array}$ & $\begin{array}{l}-0.535^{*} \\
(0.06)\end{array}$ & $\begin{array}{l}-0.224 * * * \\
(0.00)\end{array}$ & $\begin{array}{l}-0.374 * * * \\
(0.00)\end{array}$ \\
\hline Market-to-book & $\begin{array}{l}0.007 * * * \\
(0.00)\end{array}$ & $\begin{array}{l}0.007 * * * \\
(0.00)\end{array}$ & $\begin{array}{l}0.006 * * * \\
(0.00)\end{array}$ & $\begin{array}{l}0.011 \\
(0.14)\end{array}$ & $\begin{array}{l}0.005 * * * \\
(0.00)\end{array}$ & $\begin{array}{l}0.006^{* * * *} \\
(0.00)\end{array}$ \\
\hline Size & $\begin{array}{l}-0.008^{* * *} \\
(0.00)\end{array}$ & $\begin{array}{l}-0.006 * * * \\
(0.00)\end{array}$ & $\begin{array}{l}-0.001 \\
(0.75)\end{array}$ & $\begin{array}{l}-0.007 \\
(0.19)\end{array}$ & $\begin{array}{l}-0.005 \\
(0.12)\end{array}$ & $\begin{array}{l}-0.005 * * \\
(0.03)\end{array}$ \\
\hline Ind. $\mathrm{CF}$ volatility & $\begin{array}{l}0.012 * * * \\
(0.04)\end{array}$ & $\begin{array}{l}0.010^{* * *} \\
(0.04)\end{array}$ & $\begin{array}{l}0.017 * * * \\
(0.00)\end{array}$ & $\begin{array}{l}0.004 \\
(0.30)\end{array}$ & $\begin{array}{l}0.000 \\
(0.99)\end{array}$ & $\begin{array}{l}0.001 \\
(0.22)\end{array}$ \\
\hline R\&D expenditures & $\begin{array}{l}0.020 * * * \\
(0.00)\end{array}$ & $\begin{array}{l}0.019 * * * \\
(0.00)\end{array}$ & $\begin{array}{l}0.020 * * * \\
(0.00)\end{array}$ & $\begin{array}{l}0.070 * * * \\
(0.00)\end{array}$ & $\begin{array}{l}0.006^{* * *} \\
(0.00)\end{array}$ & $\begin{array}{l}0.014 * * * \\
(0.00)\end{array}$ \\
\hline Dividend dummy & $\begin{array}{l}-0.071^{* * *} \\
(0.00)\end{array}$ & $\begin{array}{l}-0.059^{* * *} \\
(0.00)\end{array}$ & $\begin{array}{l}-0.086^{* * *} \\
(0.00)\end{array}$ & $\begin{array}{l}-0.055^{* *} \\
(0.04)\end{array}$ & $\begin{array}{l}0.011^{* * *} \\
(0.00)\end{array}$ & $\begin{array}{l}-0.029 * * * \\
(0.00)\end{array}$ \\
\hline Intercept & $\begin{array}{l}0.287 * * * \\
(0.00)\end{array}$ & $\begin{array}{l}0.069 * * * \\
(0.00)\end{array}$ & $\begin{array}{l}0.035 \\
(0.17) \\
\end{array}$ & $\begin{array}{l}0.193 * * * \\
(0.00)\end{array}$ & $\begin{array}{l}0.203 * * * \\
(0.00)\end{array}$ & $\begin{array}{l}0.215^{* * * *} \\
(0.00)\end{array}$ \\
\hline Year fixed effects & Yes & Yes & No & No & Yes & Yes \\
\hline Firm fixed effects & No & No & No & No & Yes & No \\
\hline Industry fixed effect & No & No & No & No & No & Yes \\
\hline Observations & 68,057 & 68,057 & 10,760 & 286 & 68,057 & 68,057 \\
\hline Adjusted $\mathrm{R}^{2}$ & 0.26 & 0.29 & 0.34 & 0.47 & 0.75 & 0.37 \\
\hline
\end{tabular}




\section{Table 5. Cash Holdings and Skilled Labor: Subsamples of Industries with Similar Characteristics}

This table reports regression results regarding the impact of firms' reliance on skilled labor on their cash holdings for industries with reasonably similar characteristics. In Model 1, we focus on industries with above-median LSI. In Model 2, we focus on manufacturing industries (i.e., firms with SIC codes between 2,000 and 3,999). Model 3 reports the results for the subsample of manufacturing industries with above-median LSI. All regressions include year dummies. All variables are defined in Tables 1 and 2 . The $p$-values in parentheses are based on robust standard errors clustered at the industry level. $* * *, * *$, and $*$ denote statistical significance at the $1 \%, 5 \%$, and $10 \%$ levels, respectively.

\begin{tabular}{|c|c|c|c|}
\hline Variables & $\begin{array}{l}\text { High-skill } \\
\text { Industries } \\
\text { (1) }\end{array}$ & $\begin{array}{c}\text { Manufacturing } \\
\text { Industries } \\
(2) \\
\end{array}$ & $\begin{array}{c}\text { High-skill } \\
\text { Manufacturing } \\
\text { Industries } \\
(3) \\
\end{array}$ \\
\hline LSI & $\begin{array}{l}0.089 * * * \\
(0.00)\end{array}$ & $\begin{array}{l}0.154 * * * \\
(0.00)\end{array}$ & $\begin{array}{l}0.158^{* * * *} \\
(0.00)\end{array}$ \\
\hline Cash flow & $\begin{array}{l}0.005 \\
(0.13)\end{array}$ & $\begin{array}{l}0.009 \\
(0.12)\end{array}$ & $\begin{array}{l}0.005 \\
(0.49)\end{array}$ \\
\hline Net working capital & $\begin{array}{l}-0.027 * * * \\
(0.00)\end{array}$ & $\begin{array}{l}-0.036^{* * *} \\
(0.00)\end{array}$ & $\begin{array}{l}-0.030 * * * \\
(0.00)\end{array}$ \\
\hline Capital expenditures & $\begin{array}{l}-0.576^{* * *} \\
(0.00)\end{array}$ & $\begin{array}{l}-0.586 * * * \\
(0.00)\end{array}$ & $\begin{array}{l}-0.792 * * * \\
(0.00)\end{array}$ \\
\hline Leverage & $\begin{array}{l}-0.133^{* * *} \\
(0.00)\end{array}$ & $\begin{array}{l}-0.143^{* * *} \\
(0.00)\end{array}$ & $\begin{array}{l}-0.134 * * * \\
(0.00)\end{array}$ \\
\hline Acquisitions & $\begin{array}{l}-0.553 * * * \\
(0.00)\end{array}$ & $\begin{array}{l}-0.439 * * * \\
(0.00)\end{array}$ & $\begin{array}{l}-0.634 * * * \\
(0.00)\end{array}$ \\
\hline Market-to-book & $\begin{array}{l}0.007 * * * \\
(0.00)\end{array}$ & $\begin{array}{l}0.006 * * * \\
(0.00)\end{array}$ & $\begin{array}{l}0.006^{* * *} \\
(0.00)\end{array}$ \\
\hline Size & $\begin{array}{l}-0.003 \\
(0.39)\end{array}$ & $\begin{array}{l}-0.003 \\
(0.28)\end{array}$ & $\begin{array}{l}0.003 \\
(0.19)\end{array}$ \\
\hline Ind. $\mathrm{CF}$ volatility & $\begin{array}{l}0.019 * * \\
(0.04)\end{array}$ & $\begin{array}{l}0.009^{*} \\
(0.08)\end{array}$ & $\begin{array}{l}0.017^{*} \\
(0.06)\end{array}$ \\
\hline $\mathrm{R} \& \mathrm{D}$ expenditures & $\begin{array}{l}0.018 * * * \\
(0.00)\end{array}$ & $\begin{array}{l}0.018 * * * \\
(0.00)\end{array}$ & $\begin{array}{l}0.017 * * * \\
(0.00)\end{array}$ \\
\hline Dividend dummy & $\begin{array}{l}-0.093 * * * \\
(0.00)\end{array}$ & $\begin{array}{l}-0.072 * * * \\
(0.00)\end{array}$ & $\begin{array}{l}-0.119 * * * \\
(0.00)\end{array}$ \\
\hline Intercept & $\begin{array}{l}0.047 \\
(0.63) \\
\end{array}$ & $\begin{array}{l}-0.095 \\
(0.12) \\
\end{array}$ & $\begin{array}{l}-0.122 \\
(0.35)\end{array}$ \\
\hline $\begin{array}{l}\text { Year fixed effects } \\
\text { Observations } \\
\text { Adjusted } \mathrm{R}^{2}\end{array}$ & $\begin{array}{l}\text { Yes } \\
34,017 \\
0.28\end{array}$ & $\begin{array}{l}\text { Yes } \\
34,326 \\
0.34\end{array}$ & $\begin{array}{l}\text { Yes } \\
17,455 \\
0.30\end{array}$ \\
\hline
\end{tabular}




\section{Table 6. Cash Holdings and Skilled Labor: Propensity Score Matching}

This table presents our findings for matched samples with varying labor skill levels. It reports the results of the propensity score matching used to test for differences in cash holdings between firms with above-median LSI and matched firms with below-median LSI, using the nearest-neighbor matching technique. We match firms on industry (two-digit SIC codes), year, and all the control variables from our baseline specification. We report the results for the whole sample and for subsamples of industries and firms with reasonably similar characteristics (manufacturing industries, high-skill industries, positive-R\&D firms, and zero-R\&D firms), using the median level of LSI within the subsample to split firms. Manufacturing industries are defined as industries with SIC codes between 2,000 and 3,999. High-skill industries are defined as industries with above-median LSI. All variables are defined in Tables 1 and 2. ***,**, and * denote statistical significance at the $1 \%, 5 \%$, and $10 \%$ levels, respectively.

$\begin{array}{cccc}\text { Firms with } & \text { Matched firms with } & \text { Difference } \\ \text { above-median LSI } & \text { (bootstrapped } \\ \text { below-median LSI } & \text { standard errors) } & \begin{array}{c}\text { Difference } \\ \text { (standard errors } \\ \text { clustered at }\end{array} \\ \text { industry level) }\end{array}$

Whole Sample:

Cash holdings

Observations
0.177

34,024

Manufacturing Industries:

Cash holdings

Observations
0.261

34,017

17,014

High-skill Industries:

Cash holdings

16,984

0.246

$0.046^{* * *}$

$0.046 * *$

Observations

Positive-R\&D Firms:

Cash holdings

16,437

Observations

Zero-R\&D Firms:

Cash holdings

0.134

17,464

0.277

$0.077 * * *$

$0.077 * * *$

16,454

Observations

0.115

$0.019 * * *$

$0.019 *$ 


\section{Table 7. Exogenous Shock to Labor Markets: The Effect of Hurricane Katrina}

This table shows how the relation between firms' reliance on skilled labor and their cash holdings was affected by an exogenous shock to the labor supply resulting from labor migration from New Orleans to Houston following Hurricane Katrina. Houston is a dummy variable that takes the value one for companies headquartered in the Houston metropolitan area, and zero for matched companies headquartered in neighboring metropolitan areas that were not impacted by Katrina, either directly or indirectly. Post is a dummy variable that takes the value one (zero) for the year following (preceding) Katrina. We match firms on year, industry (threedigit SIC codes in Model 1 and two-digit SIC codes in Model 2), and all the control variables from our baseline specification. All variables, except the two dummy variables listed above, are defined in Tables 1 and 2 . The $p$ values in parentheses are based on robust standard errors clustered at the industry level. ***,**, and * denote statistical significance at the $1 \%, 5 \%$, and $10 \%$ levels, respectively.

\begin{tabular}{|c|c|c|}
\hline \multicolumn{3}{|c|}{ Katrina effect } \\
\hline Variables & (1) & (2) \\
\hline LSI*Houston*Post & & $\begin{array}{l}-0.160 * * * \\
(0.00)\end{array}$ \\
\hline LSI*Houston & & $\begin{array}{l}0.045 \\
(0.29)\end{array}$ \\
\hline LSI*Post & & $\begin{array}{l}0.133 * * * \\
(0.00)\end{array}$ \\
\hline LSI & & $\begin{array}{l}0.066^{*} \\
(0.07)\end{array}$ \\
\hline Houston*Post & $\begin{array}{l}-0.047 * * \\
(0.04)\end{array}$ & $\begin{array}{l}0.359 * * * \\
(0.00)\end{array}$ \\
\hline Houston & $\begin{array}{l}-0.016 \\
(0.47)\end{array}$ & $\begin{array}{l}-0.135 \\
(0.20)\end{array}$ \\
\hline Post & $\begin{array}{l}0.064 * * * \\
(0.00)\end{array}$ & $\begin{array}{l}-0.265^{* *} \\
(0.02)\end{array}$ \\
\hline Cash flow & $\begin{array}{l}-0.007 \\
(0.86)\end{array}$ & $\begin{array}{l}0.027 \\
(0.29)\end{array}$ \\
\hline Net working capital & $\begin{array}{l}-0.097 * * * \\
(0.00)\end{array}$ & $\begin{array}{l}-0.024 \\
(0.27)\end{array}$ \\
\hline Capital expenditures & $\begin{array}{l}-0.417^{* * *} \\
(0.00)\end{array}$ & $\begin{array}{l}-0.555^{* * * *} \\
(0.00)\end{array}$ \\
\hline Leverage & $\begin{array}{l}-0.219^{* * * *} \\
(0.00)\end{array}$ & $\begin{array}{l}-0.116^{* * * *} \\
(0.00)\end{array}$ \\
\hline Acquisitions & $\begin{array}{l}-0.244^{* * * *} \\
(0.00)\end{array}$ & $\begin{array}{l}-0.332 * * * \\
(0.00)\end{array}$ \\
\hline Market-to-book & $\begin{array}{l}0.003 \\
(0.54)\end{array}$ & $\begin{array}{l}0.013 * * * \\
(0.00)\end{array}$ \\
\hline Size & $\begin{array}{l}-0.011 * * \\
(0.03)\end{array}$ & $\begin{array}{l}-0.015^{* * * *} \\
(0.00)\end{array}$ \\
\hline Ind. CF volatility & $\begin{array}{l}0.011 \\
(0.42)\end{array}$ & $\begin{array}{l}0.001 \\
(0.96)\end{array}$ \\
\hline R\&D expenditures & $\begin{array}{l}0.029 * * * \\
(0.00)\end{array}$ & $\begin{array}{l}0.018 * * * \\
(0.00)\end{array}$ \\
\hline Dividend dummy & $\begin{array}{l}-0.055^{* * *} \\
(0.00)\end{array}$ & $\begin{array}{l}-0.032 * \\
(0.05)\end{array}$ \\
\hline Intercept & $\begin{array}{l}0.291 * * * \\
(0.00)\end{array}$ & $\begin{array}{l}0.130 \\
(0.20) \\
\end{array}$ \\
\hline Year fixed effects & No & No \\
\hline $\begin{array}{l}\text { Observations } \\
\text { Adjusted } \mathrm{R}^{2}\end{array}$ & $\begin{array}{l}632 \\
0.32\end{array}$ & $\begin{array}{l}632 \\
0.38\end{array}$ \\
\hline
\end{tabular}




\section{Table 8. Cash Holdings and Skilled Labor: Downward vs. Upward Adjustment Costs}

This table presents our findings on how the relation between a firm's reliance on skilled labor and its cash holdings is affected by exogenous variations in downward versus upward adjustment costs. We examine how differences in the costs of firing or hiring across states affect the relation between LSI and cash holdings. Model 1 investigates how differences in the costs of firing affect this relation. WDL measures the strength of Wrongful Discharge Laws (WDLs) in a state and is constructed by summing three distinct dummy variables for each of the three WDLs exceptions, where each dummy is set equal to one if the firm is in a state that has adopted the exception in question, and zero otherwise. Model 2 examines how differences in the costs of hiring across states affect the LSI and cash holdings relation. Hiring credits is a dummy variable that takes the value one if the quality rating of the job creation subsidies within the state in which the firm is headquartered is $\mathrm{C}$ - or above, and zero otherwise (Mattera et al. 2011). In Model 3, we examine how differences in firing and hiring costs affect the LSI and cash holdings relation concurrently. All variables, except the dummy variables listed above, are defined in Tables 1 and 2. The $p$-values in parentheses are based on robust standard errors clustered at the industry level. $* * *, * *$, and $*$ denote statistical significance at the $1 \%, 5 \%$, and $10 \%$ levels, respectively.

\begin{tabular}{|c|c|c|c|}
\hline Variables & (1) & (2) & (3) \\
\hline LSI & $\begin{array}{l}0.042 * * * \\
(0.01)\end{array}$ & $\begin{array}{l}0.102 * * * \\
(0.00)\end{array}$ & $\begin{array}{l}0.063 * * * \\
(0.00)\end{array}$ \\
\hline WDL & $\begin{array}{l}-0.020 \\
(0.25)\end{array}$ & & $\begin{array}{l}-0.012 \\
(0.39)\end{array}$ \\
\hline $\mathrm{LSI} * \mathrm{WDL}$ & $\begin{array}{l}0.022 * * * \\
(0.00)\end{array}$ & & $\begin{array}{l}0.016 * * * \\
(0.00)\end{array}$ \\
\hline Hiring credits & & $\begin{array}{l}0.052 \\
(0.13)\end{array}$ & $\begin{array}{l}0.030 \\
(0.29)\end{array}$ \\
\hline LSI $*$ Hiring credits & & $\begin{array}{l}-0.041^{* * *} \\
(0.00)\end{array}$ & $\begin{array}{l}-0.025^{* *} \\
(0.04)\end{array}$ \\
\hline Cash flow & $\begin{array}{l}0.010 * * * \\
(0.00)\end{array}$ & $\begin{array}{l}0.011 * * * \\
(0.00)\end{array}$ & $\begin{array}{l}0.011 * * * \\
(0.00)\end{array}$ \\
\hline Net working capital & $\begin{array}{l}-0.030 * * * \\
(0.00)\end{array}$ & $\begin{array}{l}-0.031 * * * \\
(0.00)\end{array}$ & $\begin{array}{l}-0.030 * * * \\
(0.00)\end{array}$ \\
\hline Capital expenditures & $\begin{array}{l}-0.433^{* * *} \\
(0.00)\end{array}$ & $\begin{array}{l}-0.374 * * * \\
(0.00)\end{array}$ & $\begin{array}{l}-0.396 * * * \\
(0.00)\end{array}$ \\
\hline Leverage & $\begin{array}{l}-0.129 * * * \\
(0.00)\end{array}$ & $\begin{array}{l}-0.130 * * * \\
(0.00)\end{array}$ & $\begin{array}{l}-0.128 * * * \\
(0.00)\end{array}$ \\
\hline Acquisitions & $\begin{array}{l}-0.403^{* * *} \\
(0.00)\end{array}$ & $\begin{array}{l}-0.407 * * * \\
(0.00)\end{array}$ & $\begin{array}{l}-0.401^{* * * *} \\
(0.00)\end{array}$ \\
\hline Market-to-book & $\begin{array}{l}0.006^{* * * *} \\
(0.00)\end{array}$ & $\begin{array}{l}0.007 * * * \\
(0.00)\end{array}$ & $\begin{array}{l}0.006^{* * * *} \\
(0.00)\end{array}$ \\
\hline Size & $\begin{array}{l}-0.007 * * * \\
(0.00)\end{array}$ & $\begin{array}{l}-0.006^{* * *} \\
(0.00)\end{array}$ & $\begin{array}{l}-0.007 * * * \\
(0.00)\end{array}$ \\
\hline Ind. $\mathrm{CF}$ volatility & $\begin{array}{l}0.011 * \\
(0.08)\end{array}$ & $\begin{array}{l}0.011 * \\
(0.07)\end{array}$ & $\begin{array}{l}0.011 * \\
(0.08)\end{array}$ \\
\hline R\&D expenditures & $\begin{array}{l}0.019 * * * \\
(0.00)\end{array}$ & $\begin{array}{l}0.020 * * * \\
(0.00)\end{array}$ & $\begin{array}{l}0.019 * * * \\
(0.00)\end{array}$ \\
\hline Dividend dummy & $\begin{array}{l}-0.054 * * * \\
(0.00)\end{array}$ & $\begin{array}{l}-0.058^{* * * *} \\
(0.00)\end{array}$ & $\begin{array}{l}-0.054^{* * * *} \\
(0.00)\end{array}$ \\
\hline Intercept & $\begin{array}{l}0.108^{* *} \\
(0.01)\end{array}$ & $\begin{array}{c}0.039 \\
(0.17)\end{array}$ & $\begin{array}{l}0.079 * * \\
(0.03)\end{array}$ \\
\hline Year fixed effects & Yes & Yes & Yes \\
\hline Observations & 50,861 & 50,833 & 50,833 \\
\hline Adjusted $\mathrm{R}^{2}$ & 0.31 & 0.30 & 0.31 \\
\hline
\end{tabular}




\section{Table 9. Cash Holdings and Skilled Labor: The Effect of Financial Constraints}

This table presents the impact of skilled labor on cash holdings for constrained (Const.) versus unconstrained (Unconst.) firms. We measure the degree of financial constraints using three different proxies: the Size and Age (SA) index (Hadlock and Pierce 2010), the Kaplan and Zingales (1997) (KZ) index, and the Whited and Wu (2006) (WW) index. The SA index is defined as $-0.737 \times$ Size $+0.043 \times$ Size $^{2}-0.040 \times$ Age. The KZ index is defined as $-1.002 \times$ Cash flow $+0.283 \times$ Tobin's $q+3.139 \times$ Debt $-39.368 \times$ Dividends $-1.315 \times$ Cash holdings. The WW index is defined as $-0.091 \times$ Cash flow $-0.062 \times$ Dividend dummy $+0.021 \times$ Long-term debt $-0.044 \times$ Size $+0.102 \times$ Industry sales growth $-0.035 \times$ Sales growth. Age is the number of years since the firm has been listed. Dividends is the ratio of common dividends (dvc) to total assets (at). Sales growth is measured as (sales in year $t$ minus sales in year $t-1$ ) / (sales in year $t-1$ ). Industry Sales growth is the average sales growth of firms belonging to the same three-digit SIC-code industry. For each year, we define firms with above (below)-median scores on the SA, KZ, and WW indices as constrained (unconstrained). The last row reports the $p$-values of the F-test for differences between the coefficients on LSI for the two subsamples of constrained and unconstrained firms. All models include year dummies. All variables are defined in Tables 1 and 2. The $p$-values in parentheses are based on robust standard errors clustered at the industry level. ***,**, and $*$ denote statistical significance at the $1 \%, 5 \%$, and $10 \%$ levels, respectively.

\begin{tabular}{|c|c|c|c|c|c|c|}
\hline \multirow[b]{2}{*}{ Variables } & \multicolumn{2}{|c|}{ SA index } & \multicolumn{2}{|c|}{ KZ index } & \multicolumn{2}{|c|}{ WW index } \\
\hline & $\begin{array}{l}\text { Const. } \\
\text { (1) }\end{array}$ & $\begin{array}{l}\text { Unconst. } \\
\text { (2) }\end{array}$ & $\begin{array}{l}\text { Const. } \\
\text { (3) }\end{array}$ & $\begin{array}{l}\text { Unconst. } \\
\text { (4) }\end{array}$ & $\begin{array}{l}\text { Const. } \\
\text { (5) }\end{array}$ & $\begin{array}{l}\text { Unconst. } \\
\text { (6) }\end{array}$ \\
\hline LSI & $\begin{array}{l}0.093 * * * \\
(0.00)\end{array}$ & $\begin{array}{l}0.061 * * * \\
(0.00)\end{array}$ & $\begin{array}{l}0.067 * * * \\
(0.00)\end{array}$ & $\begin{array}{l}0.043 * * * \\
(0.00)\end{array}$ & $\begin{array}{l}0.094 * * * \\
(0.00)\end{array}$ & $\begin{array}{l}0.047 * * * \\
(0.00)\end{array}$ \\
\hline Cash flow & $\begin{array}{l}-0.013 * * \\
(0.03)\end{array}$ & $\begin{array}{l}-0.246^{* * *} \\
(0.00)\end{array}$ & $\begin{array}{l}0.001 \\
(0.70)\end{array}$ & $\begin{array}{l}-0.250^{* * *} \\
(0.00)\end{array}$ & $\begin{array}{l}-0.004 \\
(0.32)\end{array}$ & $\begin{array}{l}0.085^{* * *} \\
(0.00)\end{array}$ \\
\hline Net working capital & $\begin{array}{l}-0.034 * * * \\
(0.00)\end{array}$ & $\begin{array}{l}-0.218^{* * *} \\
(0.00)\end{array}$ & $\begin{array}{l}0.003 \\
(0.26)\end{array}$ & $\begin{array}{l}-0.301 * * * \\
(0.00)\end{array}$ & $\begin{array}{l}-0.020 * * * \\
(0.00)\end{array}$ & $\begin{array}{l}-0.167^{* * *} \\
(0.00)\end{array}$ \\
\hline Capital expenditures & $\begin{array}{l}-0.620 * * * \\
(0.00)\end{array}$ & $\begin{array}{l}-0.387 * * * \\
(0.00)\end{array}$ & $\begin{array}{l}-0.253^{* * * *} \\
(0.00)\end{array}$ & $\begin{array}{l}-0.647 * * * \\
(0.00)\end{array}$ & $\begin{array}{l}-0.591 * * * \\
(0.00)\end{array}$ & $\begin{array}{l}-0.351 * * * \\
(0.00)\end{array}$ \\
\hline Leverage & $\begin{array}{l}-0.143^{* * *} \\
(0.00)\end{array}$ & $\begin{array}{l}-0.222 * * * \\
(0.00)\end{array}$ & $\begin{array}{l}-0.054 * * * \\
(0.00)\end{array}$ & $\begin{array}{l}-0.375^{* * *} \\
(0.00)\end{array}$ & $\begin{array}{l}-0.110 * * * \\
(0.00)\end{array}$ & $\begin{array}{l}-0.241 * * * \\
(0.00)\end{array}$ \\
\hline Acquisitions & $\begin{array}{l}-0.654 * * * \\
(0.00)\end{array}$ & $\begin{array}{l}-0.300^{* * *} \\
(0.00)\end{array}$ & $\begin{array}{l}-0.277 * * * \\
(0.00)\end{array}$ & $\begin{array}{l}-0.419 * * * \\
(0.00)\end{array}$ & $\begin{array}{l}-0.496^{* * *} \\
(0.00)\end{array}$ & $\begin{array}{l}-0.274 * * * \\
(0.00)\end{array}$ \\
\hline Market-to-book & $\begin{array}{l}0.008 * * * \\
(0.00)\end{array}$ & $\begin{array}{l}0.027 * * * \\
(0.00)\end{array}$ & $\begin{array}{l}0.008 * * * \\
(0.00)\end{array}$ & $\begin{array}{l}0.056^{* * *} \\
(0.00)\end{array}$ & $\begin{array}{l}0.006 * * * \\
(0.00)\end{array}$ & $\begin{array}{l}0.016 * * * \\
(0.00)\end{array}$ \\
\hline Size & $\begin{array}{l}0.029 * * * \\
(0.00)\end{array}$ & $\begin{array}{l}-0.012 * * * \\
(0.00)\end{array}$ & $\begin{array}{l}-0.003 \\
(0.19)\end{array}$ & $\begin{array}{l}-0.011 \text { *** } \\
(0.00)\end{array}$ & $\begin{array}{l}0.004 \\
(0.49)\end{array}$ & $\begin{array}{l}-0.009 * * * \\
(0.00)\end{array}$ \\
\hline Ind. $C F$ volatility & $\begin{array}{l}0.023 * * * \\
(0.00)\end{array}$ & $\begin{array}{l}0.006 * * \\
(0.03)\end{array}$ & $\begin{array}{l}0.010^{* * *} \\
(0.04)\end{array}$ & $\begin{array}{l}0.006 \\
(0.11)\end{array}$ & $\begin{array}{l}0.016^{* *} \\
(0.03)\end{array}$ & $\begin{array}{l}0.003 * \\
(0.09)\end{array}$ \\
\hline R\&D expenditures & $\begin{array}{l}0.016 * * * \\
(0.00)\end{array}$ & $\begin{array}{l}0.030 * * * \\
(0.00)\end{array}$ & $\begin{array}{l}0.017 * * * \\
(0.00)\end{array}$ & $\begin{array}{l}0.015 * * * \\
(0.00)\end{array}$ & $\begin{array}{l}0.017 * * * \\
(0.00)\end{array}$ & $\begin{array}{l}0.039 * * * \\
(0.00)\end{array}$ \\
\hline Dividend dummy & $\begin{array}{l}-0.078 * * * \\
(0.00)\end{array}$ & $\begin{array}{l}-0.036^{* * *} \\
(0.00)\end{array}$ & $\begin{array}{l}-0.052 * * * \\
(0.00)\end{array}$ & $\begin{array}{l}-0.074 * * * \\
(0.00)\end{array}$ & $\begin{array}{l}-0.043 * * \\
(0.03)\end{array}$ & $\begin{array}{l}-0.045 * * * \\
(0.00)\end{array}$ \\
\hline Intercept & $\begin{array}{l}-0.040 \\
(0.24) \\
\end{array}$ & $\begin{array}{l}0.185 * * * \\
(0.00)\end{array}$ & $\begin{array}{l}0.004 \\
(0.89) \\
\end{array}$ & $\begin{array}{l}0.218^{* * *} \\
(0.00)\end{array}$ & $\begin{array}{l}-0.038 \\
(0.38) \\
\end{array}$ & $\begin{array}{l}0.186^{* * * *} \\
(0.00)\end{array}$ \\
\hline Year fixed effects & Yes & Yes & Yes & Yes & Yes & Yes \\
\hline Observations & 18,345 & 18,352 & 34,025 & 34,032 & 27,668 & 27,672 \\
\hline $\begin{array}{l}\text { Adjusted } \mathrm{R}^{2} \\
p \text {-value }(F \text {-test of } \\
\text { equal coefficient } \\
\text { estimates on LSI })\end{array}$ & $\begin{array}{l}0.29 \\
(0.00)\end{array}$ & 0.43 & $\begin{array}{l}0.29 \\
(0.06)\end{array}$ & 0.52 & $\begin{array}{l}0.24 \\
(0.00)\end{array}$ & 0.33 \\
\hline
\end{tabular}




\section{Table 10. Cash Holdings and Skilled Labor: Labor Adjustment Costs or Intangible Capital?}

This table examines whether the relation between a firm's reliance on skilled labor and its cash holdings is driven by labor adjustment costs or intangible capital. Models 1-3 report the results for the whole sample. In Models 4-6, we present the results for the high-skill firms (above-median LSI firms). Models 1 and 4 report the results for firms with no R\&D spending. In Models 2 and 5, we include Intangible capital as an additional control. In Models 3 and 6, we examine the impact of LSI on cash holdings for firms with low intangible capital (bottom 30th percentile). We follow Peters and Taylor (2017) and define Intangible capital as the sum of internally created and externally purchased intangible capital. We measure the stock of internally created intangible capital as the sum of Knowledge capital, which we estimate by accumulating past R\&D spending using the perpetual inventory method, and Organizational capital, which we estimate by accumulating a fraction (30\%) of past selling, general, and administrative (SG\&A) expenses using the same method. Externally purchased intangible capital is the balance sheet item Intangible Assets (intan). We scale Intangible capital by the book value of total assets (at). All models include year dummies. All variables are defined in Tables 1 and 2 of the paper. The $p$-values in parentheses are based on robust standard errors clustered at the industry level. ***, $* *$, and $*$ denote statistical significance at the $1 \%, 5 \%$, and $10 \%$ levels, respectively.

\begin{tabular}{|c|c|c|c|c|c|c|}
\hline \multirow[b]{2}{*}{ Variables } & \multicolumn{3}{|c|}{ Whole sample } & \multicolumn{3}{|c|}{ High-skill firms } \\
\hline & $\begin{array}{c}\text { Zero- } \\
\text { R\&D } \\
(1)\end{array}$ & $\begin{array}{c}\mathrm{IC} \\
\text { control } \\
(2)\end{array}$ & $\begin{array}{l}\text { Low } \\
\text { IC } \\
(3) \\
\end{array}$ & $\begin{array}{c}\text { Zero- } \\
\text { R\&D } \\
(4)\end{array}$ & $\begin{array}{c}\mathrm{IC} \\
\text { control } \\
(5)\end{array}$ & $\begin{array}{c}\text { Low } \\
\text { IC } \\
(6) \\
\end{array}$ \\
\hline LSI & $\begin{array}{l}0.025 * * * \\
(0.01)\end{array}$ & $\begin{array}{l}0.087 * * * \\
(0.00)\end{array}$ & $\begin{array}{l}0.049 * * * \\
(0.00)\end{array}$ & $\begin{array}{l}0.060 * * * \\
(0.00)\end{array}$ & $\begin{array}{l}0.078^{* *} \\
(0.03)\end{array}$ & $\begin{array}{l}0.129 * * * \\
(0.00)\end{array}$ \\
\hline Intangible capital & & $\begin{array}{l}0.020 * * \\
(0.02)\end{array}$ & $\begin{array}{l}0.101^{*} \\
(0.08)\end{array}$ & & $\begin{array}{l}0.020 * * \\
(0.02)\end{array}$ & $\begin{array}{l}0.121^{* *} \\
(0.02)\end{array}$ \\
\hline Cash flow & $\begin{array}{l}0.002 \\
(0.61)\end{array}$ & $\begin{array}{l}0.008^{* *} \\
(0.02)\end{array}$ & $\begin{array}{l}0.029 * * \\
(0.04)\end{array}$ & $\begin{array}{l}-0.001 \\
(0.79)\end{array}$ & $\begin{array}{l}0.002 \\
(0.70)\end{array}$ & $\begin{array}{l}0.028 \\
(0.26)\end{array}$ \\
\hline Net working capital & $\begin{array}{l}-0.033^{* * *} \\
(0.00)\end{array}$ & $\begin{array}{l}-0.035^{* * *} \\
(0.00)\end{array}$ & $\begin{array}{l}-0.073^{* * *} \\
(0.00)\end{array}$ & $\begin{array}{l}-0.025^{* * *} \\
(0.00)\end{array}$ & $\begin{array}{l}-0.029^{* * * *} \\
(0.00)\end{array}$ & $\begin{array}{l}-0.082^{* *} \\
(0.03)\end{array}$ \\
\hline Capital expenditures & $\begin{array}{l}-0.188^{* * *} \\
(0.00)\end{array}$ & $\begin{array}{l}-0.429^{* * * *} \\
(0.00)\end{array}$ & $\begin{array}{l}-0.345^{* * *} \\
(0.00)\end{array}$ & $\begin{array}{l}-0.235^{* * *} \\
(0.00)\end{array}$ & $\begin{array}{l}-0.580^{* * * *} \\
(0.00)\end{array}$ & $\begin{array}{l}-0.445^{* * *} \\
(0.00)\end{array}$ \\
\hline Leverage & $\begin{array}{l}-0.099 * * * \\
(0.00)\end{array}$ & $\begin{array}{l}-0.153^{* * *} \\
(0.00)\end{array}$ & $\begin{array}{l}-0.176^{* * *} \\
(0.00)\end{array}$ & $\begin{array}{l}-0.088^{* * *} \\
(0.00)\end{array}$ & $\begin{array}{l}-0.156^{* * *} \\
(0.00)\end{array}$ & $\begin{array}{l}-0.213^{* * *} \\
(0.00)\end{array}$ \\
\hline Acquisitions & $\begin{array}{l}-0.223^{* * *} \\
(0.00)\end{array}$ & $\begin{array}{l}-0.424 * * * \\
(0.00)\end{array}$ & $\begin{array}{l}-0.255^{* * *} \\
(0.00)\end{array}$ & $\begin{array}{l}-0.281 * * * \\
(0.00)\end{array}$ & $\begin{array}{l}-0.592 * * * \\
(0.00)\end{array}$ & $\begin{array}{l}-0.402 * * * \\
(0.00)\end{array}$ \\
\hline Market-to-book & $\begin{array}{l}0.004 * * * \\
(0.00)\end{array}$ & $\begin{array}{l}0.006^{* * * *} \\
(0.00)\end{array}$ & $\begin{array}{l}0.009 * * * \\
(0.00)\end{array}$ & $\begin{array}{l}0.004 * * * \\
(0.00)\end{array}$ & $\begin{array}{l}0.007 * * * \\
(0.00)\end{array}$ & $\begin{array}{l}0.009 * * * \\
(0.00)\end{array}$ \\
\hline Size & $\begin{array}{l}-0.010^{* * *} \\
(0.00)\end{array}$ & $\begin{array}{l}-0.006^{* *} \\
(0.02)\end{array}$ & $\begin{array}{l}-0.010 * * * \\
(0.00)\end{array}$ & $\begin{array}{l}-0.014 * * * \\
(0.00)\end{array}$ & $\begin{array}{l}-0.002 \\
(0.55)\end{array}$ & $\begin{array}{l}-0.007 \\
(0.23)\end{array}$ \\
\hline Ind. $C F$ volatility & $\begin{array}{l}0.004 * * * \\
(0.00)\end{array}$ & $\begin{array}{l}0.012^{* *} \\
(0.05)\end{array}$ & $\begin{array}{l}0.005^{* *} \\
(0.03)\end{array}$ & $\begin{array}{l}0.005 \\
(0.28)\end{array}$ & $\begin{array}{l}0.025^{* *} \\
(0.03)\end{array}$ & $\begin{array}{l}0.005 \\
(0.36)\end{array}$ \\
\hline Dividend dummy & $\begin{array}{l}-0.008^{*} \\
(0.08)\end{array}$ & $\begin{array}{l}-0.064^{* * *} \\
(0.00)\end{array}$ & $\begin{array}{l}-0.020 * * * \\
(0.00)\end{array}$ & $\begin{array}{l}-0.016^{*} \\
(0.05)\end{array}$ & $\begin{array}{l}-0.104^{* * *} \\
(0.00)\end{array}$ & $\begin{array}{l}-0.047^{* * *} \\
(0.00)\end{array}$ \\
\hline Intercept & $\begin{array}{l}0.153 * * * \\
(0.00)\end{array}$ & $\begin{array}{l}0.055^{* *} \\
(0.04)\end{array}$ & $\begin{array}{l}0.140 * * * \\
(0.00)\end{array}$ & $\begin{array}{l}0.074 \\
(0.22)\end{array}$ & $\begin{array}{l}0.074 \\
(0.50)\end{array}$ & $\begin{array}{l}-0.070 \\
(0.61)\end{array}$ \\
\hline Year fixed effects & Yes & Yes & Yes & Yes & Yes & Yes \\
\hline Observations & 35,020 & 60,280 & 18,092 & 13,248 & 29,470 & 8,847 \\
\hline Adjusted $\mathrm{R}^{2}$ & 0.15 & 0.26 & 0.20 & 0.16 & 0.23 & 0.26 \\
\hline
\end{tabular}

